\title{
Monitoring of Polycyclic Aromatic Hydrocarbons (PAH) in food supplements with botanicals and other ingredients on the Dutch market
}

\begin{tabular}{|r|l|}
\hline Journal: & Food Additives and Contaminants \\
\hline Manuscript ID: & TFAC-2010-304.R1 \\
\hline Manuscript Type: & Original Research Paper \\
\hline Author: & 15 -Feb-2011 \\
\hline Complete List of Authors: & $\begin{array}{l}\text { Martena, Martijn; Food and Consumer Product Safety Authority, } \\
\text { Region South, R\&D Department } \\
\text { Grutters, Michiel; Food and Consumer Product Safety Authority, } \\
\text { Laboratory } \\
\text { de Groot, Henk; VWA : Food and Consumer Product Safety } \\
\text { Authority, Region South - R\&D } \\
\text { Konings, Erik; Nestlé Research Center, Quality \& Safety } \\
\text { Rietjens, Ivonne; Wageningen University, Division of Toxicology }\end{array}$ \\
\hline Methods/Techniques: & HPLC \\
\hline Additives/Contaminants: & PAH \\
\hline Food Types: & Dietary supplements, Nutritional supplements \\
\hline
\end{tabular}




\section{Monitoring of Polycyclic Aromatic Hydrocarbons (PAH) in food supplements} containing botanicals and other ingredients on the Dutch market

M.J. Martena ${ }^{1^{*}}$, M.M.P. Grutters ${ }^{1}$, H.N. de Groot ${ }^{1}$, E.J.M. Konings ${ }^{2^{* *}}$ and I.M.C.M. Rietjens ${ }^{3}$

${ }^{1}$ Food and Consumer Product Safety Authority (VWA), P.O. Box 2168, 5600 CD Eindhoven, The Netherlands; ${ }^{2}$ Nestlé Research Center, PO Box 44, Vers-chez-les-Blanc, CH-1000 Lausanne 26, Switzerland; ${ }^{3}$ Division of Toxicology, Wageningen University, Tuinlaan 5, $6703 \mathrm{HE}$, Wageningen, The Netherlands

${ }^{*}$ Corresponding author. Email: martijn.martena@vwa.nl

${ }^{* *}$ Part of this work was done while coauthor Konings was employed by the VWA

Running title: PAH in food supplements 


\begin{abstract}
Food supplements can contain polycyclic aromatic hydrocarbons (PAH). The European Food Safety Authority (EFSA) has defined 16 priority PAH that are both genotoxic and carcinogenic and identified 8 priority PAH (PAH8) or 4 of these (PAH4) as good indicators of the toxicity and occurrence of PAH in food. The current study aimed to determine benzo[a]pyrene and other EFSA priority PAH in different categories of food supplements containing botanicals and other ingredients. In 2003 up to 2008, benzo[a]pyrene exceeded the limit of quantification (LOQ) in $553(44 \%)$ of 1258 supplements with a lower bound mean of $3.37 \mu \mathrm{g} \mathrm{kg}^{-1} . \ln 2008$ and 2009, benzo[a]pyrene and 12 other EFSA priority PAH were determined in 333 food supplements. Benzo[a]pyrene exceeded the LOQ in $210(63 \%)$ food supplements with a lower bound mean of $5.26 \mathrm{\mu g} \mathrm{kg}^{-1}$. Lower bound mean levels for PAH4 and PAH8 (-indeno[1,2,3-cd]pyrene) were $33.5 \mu \mathrm{g} \mathrm{kg}^{-1}$ and $40.5 \mu_{\mathrm{g} \mathrm{kg}}{ }^{-1}$, respectively. Supplements containing resveratrol, Ginkgo biloba, St. John's wort and propolis showed relatively high PAH4 levels in 2008 and 2009. Before 2008, supplements with these ingredients and also dong quai, green tea or valerian contained relatively high benzo[a]pyrene levels. On average, $\mathrm{PAH} 4$ intake resulting from food supplement use will be at the lower end of the range of contributions of main food groups to $\mathrm{PAH} 4$ exposure, although individual food supplements can contribute significantly to PAH4 exposure. Regular control of EFSA indicator PAH levels in food supplements may prove a way forward to further reduce the intake of PAH from food.
\end{abstract}

Keywords: benzo[a]pyrene, PAH, food supplements, herbal preparations, botanicals 


\section{Introduction}

Polycyclic aromatic hydrocarbons (PAH) can be formed during incomplete combustion or pyrolysis of organic matter and during industrial processes (SCF 2002; JECFA 2006; EFSA 2008b). PAH found in food are either derived from the environment or are directly formed during industrial food processing or domestic food preparation (JECFA 2006). Several PAH such as benzo[a]pyrene are both genotoxic and carcinogenic. In the last decade lists of priority PAH were put forward on the basis of their individual genotoxic and carcinogenic properties by the Scientific Committee on Food (SCF) of the European Union (EU), the Joint FAO/WHO Expert Committee on Food Additives (JECFA) and the European Food Safety Authority (EFSA) (SCF 2002; JECFA 2006; EFSA 2008b). The SCF identified a priority group of $15 \mathrm{PAH}$ in the risk assessment of PAH in food and concluded that benzo[a]pyrene could be used as a marker for the occurrence and effect of carcinogenic PAH in food (SCF 2002). JECFA focused on 13 of these PAH, which were identified to be genotoxic and carcinogenic (JECFA 2006). Additionally, JECFA noted that besides these 13 PAH, benzo[c]fluorene was also genotoxic and carcinogenic, but the Committee did not include this substance in their evaluation because of a lack of data on its occurrence in food (JECFA 2006). The European Commission requested Member States in Recommendation 2005/108/EC to monitor in certain foods the occurrence of the 15 priority PAH identified by the SCF (European Commission 2005). These surveys were to cover foods such as oils and fats, infant formulae and baby foods, meat, and marine products for which maximum levels of benzo[a]pyrene are specified in Regulation (EC) No. $1881 / 2006$ and other foods that can contain high levels of PAH, such as dried fruits and food supplements for which no limits yet exist in this Regulation (European Commission 2006). The data obtained would be used for future review of the suitability of maintaining benzo[a]pyrene as a marker (European Commission 2005). In 2008, the European Food Safety Authority (EFSA), which continued the work of the SCF, reviewed the available data on occurrence and toxicity of 16 priority $\mathrm{PAH}, 15$ of which were identified by SCF and one, benzo[c]fluorene, by JECFA (EFSA 2008b). Table 1 shows the priority PAH identified by SCF, JECFA and EFSA (SCF 2002; JECFA 2006; EFSA 2008b). EFSA concluded that 8 of these 16 'EFSA priority PAH' for which oral carcinogenicity data are available (PAH8) could be used as indicator - either individually or in combination - of the carcinogenic potency of PAH in food (Table 1). However, EFSA established that benzo[a]pyrene alone was not a suitable indicator of the occurrence of PAH in food (EFSA 2008b). EFSA concluded that in its place the most suitable 
indicators of PAH in food with regards to both occurrence and toxicity were currently PAH4 or PAH8 (Table 1), with PAH8 not providing much added value compared to PAH4 (EFSA 2008b).

The Dutch Commodities Act includes since January 2006 a maximum level of $10 \mu \mathrm{g} \mathrm{kg}^{-1}$ benzo[a]pyrene for food supplements with botanical ingredients and a maximum of $2 \mu \mathrm{g} \mathrm{kg}^{-1}$ benzo[a]pyrene for supplements without these ingredients (VWS 2005). These limits were introduced as a result of an ongoing survey by the Voedsel en Waren Autoriteit (VWA - the Dutch Food and Consumer Product Safety Authority) into the presence of benzo[a]pyrene in food supplements (VWS 2005). In 2006, we published the analytical method for quantification of benzo[a]pyrene together with the results of a survey of benzo[a]pyrene in a series of food supplements, mainly supplements containing botanical and fat soluble vitamin ingredients, sampled since 2003 $(n=950)$, and of other food samples ( $n=400)$ (van der Wielen et al. 2006). Of these food supplements, $30 \%$ contained benzo[a]pyrene above $1.2 \mu \mathrm{g} \mathrm{kg}^{-1}$ with levels ranging up to $200 \mu \mathrm{g} \mathrm{kg}^{-1}$. Before the legal maximum levels for benzo[a]pyrene in food supplements were introduced in 2006, a maximum level of $1.2 \mu \mathrm{g} / \mathrm{kg}$ benzo[a]pyrene was applied to these products by the VWA. In samples of raw materials for food supplements containing d-alpha tocopherol - natural vitamin E, levels of benzo[a]pyrene of up to $275 \mu \mathrm{g} \mathrm{kg}^{-1}$ were found. In this publication we did not investigate whether certain types of food supplements, depending on their ingredients, were more frequently or more heavily contaminated with benzo[a]pyrene than other types of food supplements. The primary data suggested however that supplements with natural vitamin $\mathrm{E}$ and certain botanical ingredients frequently contained relatively high benzo[a]pyrene levels. In 2005, the UK Food Standards Agency (FSA) determined the 15 SCF priority PAH in 200 food supplements (FSA 2005). EFSA published data on the 16 EFSA priority PAH in nearly 300 food supplements that also included the FSA data (FSA 2005; EFSA 2008a; EFSA 2008b; Danyi et al. 2009). In these and in other studies relatively high levels of PAH (consisting of several or all of the EFSA PAH8) were reported for various individual food supplements often containing botanical ingredients such as ginkgo, ginseng, or spirulina, or bee products such as propolis (FSA 2005; EFSA 2008a; EFSA 2008b; Dobrinas et al. 2008; Danyi et al. 2009; Moret et al. 2010). However, descriptive statistics of PAH levels in different groups of food supplements categorized by their main ingredients were not provided in these reports either.

More detailed data on levels of EFSA priority PAH in different groups of food supplements categorized by main ingredients would aid the setting of European limits for EFSA priority PAH in food supplements. 
1

2

4

5

6

7

8

9

10

11

12

13

14

15

16

17

18

19

20

21

Moreover, this information would also help to focus surveys of EFSA priority PAH in food supplements at those products with potentially high PAH levels. Because of previous reports of high levels of EFSA priority PAH in botanical food supplements (FSA 2005; EFSA 2008a; EFSA 2008b; Danyi et al. 2009), these products represent a category of special interest in this respect. Therefore, the objective of the present study was to collect data on the occurrence of benzo[a]pyrene and other EFSA priority PAH in different categories of food supplements, with special emphasis on botanical food supplements. To this end the existing analytical method was expanded to include more of the 16 EFSA priority $\mathrm{PAH}$ in addition to benzo[a]pyrene. 


\section{Material and Methods}

\section{Sampling}

For this survey food supplements were sampled on the Dutch market by inspectors of the VWA. From 2003 up to and including 2007, 1258 samples of food supplements were collected for benzo[a]pyrene analysis. In 2008 and 2009,333 food supplements were collected for the determination of benzo[a]pyrene and other EFSA priority PAH. The supplements were collected using a standardized sampling protocol twice yearly. In order to identify groups of food supplements with relatively high PAH levels, the sampling protocol was adjusted each time to include more of those types of supplements that previously showed high PAH levels. Of each sample the name of the manufacturer or distributor, the product name, the date of minimum durability, and the production lot code were routinely entered in the VWA inspection database. The supplements sampled for this study contained vitamins, botanical ingredients including fatty acids or oils, phytochemicals extracted from plants, fatty acids or oils from animal origin, and other ingredients derived from animals such as glucosamine, chitosan, green lipped mussel extract, and others. EFSA defines the term 'botanical' as all botanical materials such as whole, fragmented or cut plants, plant parts, algae, fungi, and lichens. The term 'botanical preparations' is used by EFSA to refer to all preparations obtained from botanicals by various processes (e.g. pressing, squeezing, extraction, fractionation, distillation, concentration, drying up, and fermentation)(EFSA 2009). Unless otherwise specified, the term 'botanical' can refer in the current study both to a botanical (or botanical material) or a botanical preparation as defined by EFSA. In 2003 and 2004, botanical food supplements and food supplements containing d-alpha tocopherol (natural vitamin E) were sampled most. Other samples were food supplements with other vitamins and non-botanical ingredients. In the ensuing years (2005-2009) the sampling protocols targeted mainly botanical supplements, but some non-botanical food supplements were also sampled.

\section{Grouping of supplements}

In order to identify whether certain ingredients of food supplements were contaminated with PAH to a higher extent and more frequently than others, sampling was preferentially aimed at supplements with only one main or 'active' ingredient. The 'active' ingredient refers to the ingredient that is clearly regarded by the manufacturer or distributor to show nutritional or physiological activity. The food supplements that were sampled belonged to three 
main categories: i) essential fatty acids, ii) botanicals, and iii) other substances. Where supplements could be grouped in more than one main category they were placed in the category that best defined the nature of these products. Plant oils, for instance, could be listed as botanical preparations, but were categorized instead as 'essential fatty acids'. Within each main category, subcategories were created on the basis of the active ingredients (Tables 5 and 8). Supplements from a subcategory identified by an ingredient name such as Ginkgo biloba, were mono-ingredient supplements that in principle contained no other active ingredients. In only a few cases however, botanical supplements with two active ingredients were included in a mono-ingredient botanical supplement group, but only when one botanical ingredient was accompanied by one other active ingredient (vitamin C, for example) that was not found to contain significant PAH levels in this study. In case PAH were found in such a supplement, it was concluded that these PAH were derived from the botanical ingredient. Most types of mono-ingredient supplements of which less than 5 products were sampled, were placed in several general mono-ingredient subcategories. However, some specific subcategories consisting of less than 5 samples were created for mono-ingredient supplements that were of interest due to relatively high or unanticipated low PAH levels. Food additives, substances added for technical purposes such as bulking and glazing agents, or other 'inactive' ingredients that do not characterize the supplement, were not used to categorize the supplements. Ingredients of food supplements collected in 2008 and 2009 were recorded from the containers of food supplements. Containers of food supplements collected before 2008 were not available, and ingredients of these supplements were identified by searching the Internet by using the product name and the name of the manufacturer of distributor.

\section{Experimental}

The analytical method used to determine benzo[a]pyrene in supplements sampled from 2003 up to and including 2007 has been described previously by us (van der Wielen et al. 2006). It was based on an online donor acceptor complex chromatography (DACC) cleanup prior to reversed-phase high performance liquid chromatography with fluorescence detection (van Stijn et al. 1996). In 2008, the method was altered to meet the requirements for the analysis of the 16 EFSA priority PAH. This expanded method can be described as follows. The sample was homogenized and $1 \mathrm{~g}$ of sample was then transferred to a $20 \mathrm{ml}$ volumetric flask and brought up to mark with 2propanol. After shaking for 20 minutes at 120 strokes/minute in order to extract the $\mathrm{PAH}$, the extract was filtered 
by means of a $0.45 \mu \mathrm{m}$ syringe filter and injected on a DACC column (Chromspher Pi, $80 \times 0,3 \mathrm{~mm}$ ) using 2propanol as mobile phase. After removal of matrix components using 2-propanol as the eluent, the PAH were stripped from the DACC column by means of ethylacetate - acetonitril $(70 / 30 \mathrm{v} / \mathrm{v})$ and subjected to 2 reversed phase analytical columns in series (Lichrocart 250-4 Lichrospher PAH RP-18 $5 \mu \mathrm{m}$ ) prior to quantification of the PAH by variable wavelength fluorescence detection.

Cyclopenta[cd]pyrene and benzo[]fluoranthene were not included in the method because of low fluorescence intensities. Moreover, indeno[1,2,3-cd]pyrene could also not be included. The analysis of indeno[1,2,3-cd]pyrene would require different wavelength settings, but these could not be implemented because of insufficient resolution of this PAH and dibenzo[a,e]pyrene. Use of a multi-channel fluorescence detector combined with a photo diode array detector would have allowed for the determination of these remaining three $\mathrm{PAH}$, but our routine method was not equipped with these features at that time. The main alterations to the method already described by van der Wielen et al. ( 2006) were in the mobile phase gradient and the fluorescence wavelength settings and these are presented in Tables 2 and 3, respectively. The method of analysis was in-house validated according to ISO 17025 guidelines. The limit of detection (LOD) was determined based on the signal to noise ratio. The LOD was defined as the concentration at which the peak height corresponds with 3 times the bandwidth of the noise; the limit of quantification (LOQ) was defined as 6 times the bandwidth of the noise. During the validation study, performance criteria such as precision under repeatability and reproducibility conditions, trueness, recovery and measurement uncertainty were established (Table 4). During the analyses, measurement quality was assured by means of random analysis of standard control samples of food supplements, which were monitored in time by Shewhart control charts (Thompson and Wood 2005).

\section{Intake estimates and statistics}

Intakes of benzo[a]pyrene, PAH2, PAH4 and PAH8 with a supplement when used at the maximum dose level were estimated for several supplements in which relatively high concentrations of benzo[a]pyrene were found. The daily intake of these PAH with a supplement was calculated from the weight of one unit (determined by preferably weighing 10 or more units), the analytically determined PAH level and the maximum recommended daily use level stated on the label. When a supplement consisted of capsules or soft gels, only PAH levels of its 
contents were reported and where the weight of a capsule or soft gel was needed for calculations the weight of its contents was taken.

In this study all values lower than the limit of detection (LOD) or limit of quantification (LOQ) were replaced by 0 (lower bound) in order to calculate the descriptive statistics. To aid the comparison of our data with data on PAH in food supplements on the European market published in a report of the EFSA Unit of Data Collection and Exposure in 2007 and the revised and updated report published in 2008, the descriptive statistics for the benzo[a]pyrene data obtained before 2008 included the calculation of the mean, the median, the $90^{\text {th }}$ and the 95 ${ }^{\text {th }}$ percentiles (P90 and P95, respectively) and the maximum (EFSA 2008a). Percentiles were only calculated when sample numbers exceeded 10. For each food supplement category sampled in the 2008 and 2009 survey, mean levels of each of the 13 EFSA priority PAH were calculated and also the mean levels of benzo[a]pyrene, $\mathrm{PAH} 2, \mathrm{PAH} 4$ and $\mathrm{PAH} 8$. The data from the whole study period were compared to the maximum levels for benzo[a]pyrene defined in Dutch food law $\left(10 \mu \mathrm{g} \mathrm{kg}^{-1}\right.$ for botanical and $2 \mu \mathrm{g} \mathrm{kg}^{-1}$ for regular food supplements) and, following the approach of EFSA, to all maximum levels for this PAH existing in Regulation (EC) No. 1881/2006, also because supplements are not yet regulated by this Regulation in this respect (VWS 2005; European Commission 2006). Existing maximum levels for benzo[a]pyrene in Regulation (EC) No. 1881/2006 are: $1 \mu \mathrm{g} \mathrm{kg}^{-1}$ for baby foods, infant formulae, follow on formulae and other infant foods, $2 \mu \mathrm{g} \mathrm{kg}^{-1}$ for oils, fats and fish, $5 \mu \mathrm{g} \mathrm{kg}^{-1}$ for smoked meat and fish and some marine products, and $10 \mu \mathrm{g} \mathrm{kg}^{-1}$ for bivalve mollusks (European Commission 2006).

FSA reported in 2005 levels of 15 SCF priority PAH in 207 individual food supplements from different supplement categories. Levels of 15 SCF priority PAH above the LOD were reported for each individual sample separately (FSA 2005). The FSA report did not include descriptive statistics that would aid the comparison of our results to the FSA data. We therefore calculated from the FSA data the overall lower bound mean of the benzo[a]pyrene, PAH2, PAH4 and PAH8 levels, for which we replaced each value below the LOD by 0 . These parameters were also calculated for each food supplement category as defined by the FSA. We divided the category of 'Ginkgo/Echinacaea' in two, resulting in a separate category for each of these botanicals. 


\section{Results}

Results in 2003 up to and including 2007

The food supplements included in the study were grouped into main categories and subcategories based on the active ingredient or a combination of active ingredients. Table 5 shows for each subcategory the lower bound mean, median, P90, P95 and maximum benzo[a]pyrene levels obtained in 2003 up to and including 2007. Also shown for each category in this table is the percentage of samples with benzo[a]pyrene levels that exceeded the LOQ and limits that currently apply to benzo[a]pyrene in various foods in European and Dutch food law. Based on the Dutch limit for benzo[a]pyrene in botanical food supplements of $10 \mu \mathrm{g} \mathrm{kg}^{-1}$, benzo[a]pyrene levels in a food supplement category were considered high in the current study when the P90 of benzo[a]pyrene levels in a category exceeded $10 \mathrm{~g} \mathrm{~kg}^{-1}$. In total, 553 (44\%) of 1258 supplements contained benzo[a]pyrene levels above the LOQ and the lower bound mean benzo[a]pyrene level was $3.37 \mu \mathrm{g} \mathrm{kg}^{-1}$. For several supplements with relatively high benzo[a]pyrene concentrations, estimated intake levels of this PAH were calculated by using the manufacturers' maximum recommended use level (Table 6).

Benzo[a]pyrene levels in all samples in the category of mono-ingredient botanical food supplements, which included botanicals such as Boswellia serrata and kelp, were below $5 \mathrm{\mu g} \mathrm{kg}^{-1}$ (Table 5). A multivitamin supplement with several botanicals contained $43.4 \mu \mathrm{g} \mathrm{kg}^{-1}$ benzo[a]pyrene, which would amount to a daily intake of $229 \mathrm{ng}$ of benzo[a]pyrene when used according to the maximum recommended use levels. The parameters used for the calculation of this intake estimate are shown in Table 6 under No. 7. Supplements with green tea (Camellia sinensis) showed the highest mean and median benzo[a]pyrene concentrations in botanicals between 2003 and 2007 (Table 5). A supplement with green tea with the highest benzo[a]pyrene level found in this period of $145 \mathrm{\mu g} \mathrm{kg}^{-1}$, would provide $225 \mathrm{ng}$ of benzo[a]pyrene per day when used at the maximum recommended use level. The parameters used for the calculation of this intake estimate are shown in Table 6 under No. 4. Furthermore, supplements with a tea variety called 'pu erh', which is claimed to aid in weight loss, also showed relatively high benzo[a]pyrene levels. Moreover, benzo[a]pyrene levels were relatively high in the botanicals dong quai (Angelica sinensis), Ginkgo biloba, St. John's wort (Hypericum perforatum) and valerian (Valeriana officinalis) and outside the botanical category, in propolis and pollen supplements, and natural vitamin $\mathrm{E}$ (d-alfa 


\section{Results from 2008 up to and including 2009}

In 2008, the method for benzo[a]pyrene was expanded to include more of the 16 EFSA priority PAH. Of these priority PAH, cyclopenta[cd]pyrene, benzo[]fluoranthene and indeno[1,2,3-cd]pyrene (IcP) could not be quantified. Because indeno[1,2,3-cd]pyrene could not be determined, the PAH8 level reported in this survey lacks the levels for this PAH and was consequently referred to as PAH8(-IcP). The remaining 13 EFSA priority PAH were analyzed in 333 supplements sampled in 2008 and 2009 and the lower bound estimates for the mean benzo[a]pyrene, PAH2, PAH4, and PAH8(-IcP) levels were $5.33 \mu \mathrm{g} \mathrm{kg}^{-1}, 20.8 \mu \mathrm{g} \mathrm{kg}^{-1}, 33.8 \mu \mathrm{g} \mathrm{kg}^{-1}$, and $40.9 \mu \mathrm{g}$ $\mathrm{kg}^{-1}$, respectively. Table 7 shows for each EFSA priority PAH quantified in these 333 supplements the descriptive statistics including the lower bound mean and the percentage of the samples exceeding the LOQ, and limits that currently apply to benzo[a]pyrene in various foods in European and Dutch food law. Benzo[a]pyrene levels were above the LOQ in $210(63 \%)$ of the 333 samples. The priority PAH with the highest lower bound mean level was chrysene with a value of $15.5 \mu \mathrm{g} \mathrm{kg}^{-1}$ and the maximum level found for this PAH was $368 \mu \mathrm{g} \mathrm{kg}^{-1}$. The priority PAH with the highest maximum level was benzo[c]fluorene with $503 \mu \mathrm{g} \mathrm{kg}^{-1}$ (Table 7).

For each subcategory of supplements sampled in 2008 and 2009, mean benzo[a]pyrene, PAH2, PAH4, and PAH8(-IcP) levels were computed including the percentage of samples with benzo[a]pyrene levels that exceeded the LOQ and limits for benzo[a]pyrene in Dutch and European food law (Table 8). The results obtained in 2008 and 2009 will be discussed by focusing on the PAH4 levels. Figure 1 presents the minimum, median and maximum PAH4 levels of the different food supplement categories determined in the 2008 and 2009 survey. High PAH4 levels were defined for the purpose of the current study as a mean above $40 \mu \mathrm{g} \mathrm{kg}^{-1}$ of PAH4. This definition was based on the Dutch limit of $10 \mu \mathrm{g} \mathrm{kg}^{-1}$ for benzo[a]pyrene, which is one of the PAH4, in botanical food supplements. For several individual supplements of interest, reference is made in the text to specific entries in Table 9. This table presents for a total of 20 supplements sampled in 2008 and 2009 with relatively high PAH levels, the estimated daily intake levels of benzo[a]pyrene, $\mathrm{PAH} 2, \mathrm{PAH} 4$, and $\mathrm{PAH}(-\mathrm{IcP})$, when used at the manufacturers' maximum recommended dose level. 
Mono-ingredient botanical supplements including botanicals such as cat's claw (Uncaria tomentosa), Eleutherococcus senticosus, Echinacaea ${ }_{1}$ or red clover, showed relatively low PAH4 levels except for a supplement with brown marine algae with a PAH4 level of $84 \mathrm{\mu g} \mathrm{kg}^{-1}$ (Table 8). PAH4 levels of 17 multi-ingredient botanical supplements ( $\mathrm{n}=111$ ) were higher than $40 \mu \mathrm{g} \mathrm{kg}^{-1}$. Estimated daily PAH4 intakes for four of these supplements when used at the maximum dose level recommended by the manufacturer, ranged from 69 to 170 ng per day. Intake estimates for other PAH indicators and the parameters used to calculate these, are shown in Table 9 under Nos. 7, 8, 9, and 10. A multivitamin supplement with several botanicals such as valerian, golden root and St. John's wort was found to contain $125 \mu \mathrm{g} \mathrm{kg}^{-1}$ PAH4 and $23 \mu \mathrm{g} \mathrm{kg}^{-1}$ benzo[a]pyrene. According to the producer high PAH levels were caused by the use of a batch of St. John's wort containing $94 \mathrm{\mu g} \mathrm{kg}^{-1}$ benzo[a]pyrene. Use of this supplement at the highest recommended dose level would result in a PAH4 exposure of $99 \mathrm{ng}$ per day. Additional PAH exposure estimates and the parameters used to calculate these for this supplement are shown in Table 9 under No. 16.

In Chinese multi-ingredient botanical supplements the mean PAH4 level of $38 \mu \mathrm{g} \mathrm{kg}^{-1}$ resulted mainly from a sample with $340 \mathrm{~g} \mathrm{~kg}^{-1}$ of PAH4, while the median PAH4 level in this category was below the LOQ (Figure 1, Table 8). In mono-ingredient botanical supplements with black cohosh (Actea racemosa), dong quai, green tea, ginseng (Panax ginseng), or valerian, mean benzo[a]pyrene levels were lower in the 2008 and 2009 survey than in the survey from 2003 up to and including 2007 (Table 5 and 8). Furthermore, mean PAH4 levels in these categories from 2008 and 2009 remained below $40 \mathrm{~g} \mathrm{~kg}^{-1}$ (Table 8). The mean PAH4 level in Ginkgo biloba supplements analyzed in 2008 and $2009(\mathrm{n}=22)$ was relatively high $\left(47 \mu \mathrm{g} \mathrm{kg}^{-1}\right)$ but the median PAH4 level $\left(1.1 \mathrm{~g} \mathrm{~kg}^{-1}\right)$ was considerably lower (Figure 1, Table 8). The high mean PAH4 level mainly resulted from 5 Ginkgo biloba supplements with PAH4 levels above $40 \mu \mathrm{g} \mathrm{kg}^{-1}$ and 4 of these contained more than $100 \mu \mathrm{g} \mathrm{kg}^{-1}$ PAH4. Use of the Ginkgo biloba supplement with the highest PAH4 level of $430 \mu \mathrm{g} \mathrm{kg}^{-1}$ at the maximum recommended dose level would result in a PAH4 intake of $178 \mathrm{ng}$ per day. Additional intake estimates for other PAH indicators and the parameters used to calculate these are shown in Table 9 under No. 3. St. John's wort (Hypericum perforatum) samples from 2008 and 2009 contained relatively high PAH levels (Table 8). Compared to the Ginkgo biloba supplements sampled in 2008 and 2009, PAH contamination of St. John's wort samples from the same period was more evenly distributed over the samples and the mean PAH4 level of $40 \mathrm{\mu g} \mathrm{kg}^{-1}$ was close

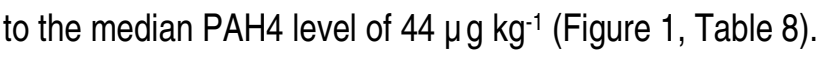


Mono-ingredient supplements with resveratrol showed the highest mean PAH4 level in 2008 and 2009. A supplement only containing resveratrol from Polygonum cuspidatum root showed the highest benzo[a]pyrene level $\left(150 \mu \mathrm{g} \mathrm{kg}^{-1}\right)$, PAH4 level $\left(812 \mu \mathrm{g} \mathrm{kg}^{-1}\right)$, and PAH8(-IcP) level $\left(1009 \mu \mathrm{g} \mathrm{kg}^{-1}\right)$ found during the whole study period from 2003 up to and including 2009. In addition, the benzo[c]fluorene level (117 $\left.\mu \mathrm{g} \mathrm{kg}^{-1}\right)$ was also high. Use at the maximum recommended dose level of this supplement would result in a PAH4 intake of $320 \mathrm{ng}$ per day. Intake estimates for other PAH and the parameters used to calculate these for this supplement are presented in Table 9 under No. 18. A multi-ingredient supplement with resveratrol, wine grape extract and quercetin contained $474 \mathrm{~g} \mathrm{~kg}^{-1}$ benzo[c]fluorene and another resveratrol supplement from the same distributor, which also included wine grape extract (OPC), green tea polyphenols, and rutin, contained $503 \mu_{\mathrm{g} \mathrm{kg}}{ }^{-1}$ benzo[c]fluorene. These benzo[c]fluorene levels were the highest levels found for any PAH in this survey and were comparable to the PAH8(-IcP) levels in these supplements (423 and $593 \mathrm{\mu g} \mathrm{kg}^{-1}$, respectively). PAH4 exposure estimates for these supplements at the maximum recommended dose level were $192 \mathrm{ng}$ and $283 \mathrm{ng}$ per day, respectively. Additionally, benzo[a]pyrene, PAH2 and PAH8 intake estimates for these supplements and the parameters used to calculate these, are shown in Table 9 under Nos. 12 and 14, respectively. Another multiingredient botanical with resveratrol contained $371 \mu_{\mathrm{g} \mathrm{kg}}{ }^{-1} \mathrm{PAH} 4$, and use of this product at the highest proposed dose level would result in a PAH4 intake level of $705 \mathrm{ng}$ per day. Additional PAH intake estimates and the parameters used to calculate these for this supplement are presented in Table 9 under No. 13.

PAH levels in supplements without botanicals were low (Table 8). However, a supplement with chitosan and vitamin $\mathrm{C}$ from this group contained $63 \mu \mathrm{g} \mathrm{kg}^{-1} \mathrm{PAH} 4$. Use of this supplement would result in $82 \mathrm{ng} \mathrm{PAH4}$ per day when used at the maximum recommended dose level. Additional PAH intake estimates and the parameters used to calculate these for this supplement are presented in Table 9 under No. 1. Furthermore, PAH4 levels in propolis supplements were overall relatively high (Figure 1, Table 8).

Table 10 shows for each of the 13 EFSA priority PAH determined in this survey the mean PAH level in each subcategory of food supplements sampled in 2008 and 2009. Supplements with resveratrol (alone or in combination with other botanicals) showed for 11 of these PAH the highest mean levels. The highest mean dibenzo[ae]pyrene and dibenzo[ah]pyrene levels were found in Chinese botanical supplements.

We calculated from FSA data on 15 SCF priority PAH in 207 individual food supplements (FSA 2005) the lower bound mean benzo[a]pyrene, $\mathrm{PAH} 2, \mathrm{PAH} 4$, and PAH8 levels, which amounted to respectively, 1.90, 
$11.0,18.3$, and $22.7 \mu \mathrm{g} \mathrm{kg}^{-1}$. These parameters were also calculated for each category of food supplements used by the FSA (Table 11). The relatively high PAH levels in the FSA category 'plant extracts' resulted mainly from individual supplements with spirulina, soy isoflavones, green tea, black cohosh, dong quai, St. John's wort, and red clover. The mean benzo[a]pyrene level of ginseng supplements (Table 11) matched best our findings for this botanical from 2003 up to and including 2007 (Table 5). A spirulina supplement with a PAH4 level of $660 \mu \mathrm{g} \mathrm{kg}^{-1}$ and a PAH8 level of $789 \mathrm{\mu g} \mathrm{kg}^{-1}$ contributed considerably to the relatively high mean PAH level in the FSA category 'other aquatic products' (Table 11). From the maximum recommended dose level reported by the FSA we calculated a daily PAH4 intake level of $3443 \mathrm{ng}_{\text {day }}{ }^{-1}$ and a daily PAH8 intake level of $4120 \mathrm{ng}$ day $^{-1}$ for this supplement. 


\section{Discussion}

\section{PAH levels of food supplements in the current study and other reports}

The current study presents levels of benzo[a]pyrene and several of the priority PAH defined in 2008 by EFSA in food supplements containing botanicals and other ingredients, such as propolis and vitamin $E$, on the Dutch market. Our results are in good agreement with reports of PAH levels of different types of food supplements. High PAH levels in propolis have been reported in several European Member States (FSA 2005; Dobrinas et al. 2008; Moret et al. 2010). High PAH levels in natural vitamin $\mathrm{E}$ of the three major manufacturers in the world were described in a US patent from 1994 (Horrobin and Manku 1997). Because natural vitamin E is obtained from plant sources such as soy or wheat by a series of concentration steps, the patent authors hypothesized that not only vitamin $\mathrm{E}$ is concentrated by this process, but also PAH are. The benzo[a]pyrene levels reported in the patent of 28, 30 and $106 \mu \mathrm{g} \mathrm{kg}^{-1}$ were in line with our results for vitamin $\mathrm{E}$ food supplements with expiry dates before 2007 (Table 5) and our previous results (van der Wielen et al. 2006). Higher benzo[a]pyrene levels were reported for 2 different natural vitamin $\mathrm{E}$ products (mixed tocopherols) from 2 Chinese manufacturers, which were $469.5 \pm 36.8$ $\mu \mathrm{g} \mathrm{kg}^{-1}$ and $315.0 \pm 9.5 \mu \mathrm{g} \mathrm{kg}^{-1}$ (Yang et al. 2008). PAH4 levels in these two products calculated from the reported individual PAH were 1700 and $900 \mathrm{\mu g} \mathrm{kg}^{-1}$ (rounded off to the nearest 100), respectively. Our results were also in agreement with a report of the FSA of 15 SCF priority PAH in a wide range of food supplements (n=207) sampled in 2004 (FSA 2005). The FSA data also showed relatively high mean PAH levels in Ginkgo biloba supplements and bee products (high levels were limited to propolis supplements). The lower bound mean benzo[a]pyrene, PAH2, PAH4, PAH8 levels $\left(1.90,11.0,18.3\right.$, and $22.7 \mu \mathrm{g} \mathrm{kg}^{-1}$, respectively) calculated from the FSA data were lower than our findings, which might be explained by differences in sampling strategies. The FSA survey covered a wide range of food supplements that were sampled in one stage; whereas our study targeted supplements with high PAH levels, which were sampled in several stages. With respect to benzo[a]pyrene, the levels reported by the FSA fitted best the data obtained by us from 2003 up to and including 2007 (Table 5). Danyi et al. determined the 16 EFSA priority PAH in 20 botanical mono-ingredient food supplements of which St. John's wort showed the highest PAH levels. Benzo[C]fluorene was found in two supplements (Danyi et al. 2009). 
The results were within the range found in our survey but the number of samples was too low for a meaningful comparison.

Maximum levels for contaminants in European Food law should be set at a level, which is as low as reasonably achievable (ALARA) when these contaminants are considered to be genotoxic carcinogens (European Commission 2006). In this respect, it was interesting to note that overall in $192(58 \%)$ of the supplements in our 2008 and 2009 survey (n=333), PAH4 levels were lower than $10 \mu \mathrm{g} \mathrm{kg}^{-1}$ and in $99(30 \%$ of the total) of these PAH4 levels were below the LOQ. Furthermore, in all subcategories of food supplements identified in this survey there were supplements that contained no quantifiable or relatively low levels (here defined as PAH4 level below $10 \mu \mathrm{g} \mathrm{kg}^{-1}$ ) of PAH. This suggests that contamination of food supplements with PAH is avoidable.

\section{PAH levels of food supplements reported by EFSA}

EFSA reported in 2008 in an Opinion of the Panel on Contaminants in the Food Chain on PAH in food, lower and upper bound mean benzo[a]pyrene, $\mathrm{PAH} 2, \mathrm{PAH} 4$, and PAH8 levels of 283 food supplements derived from data submitted to EFSA by five European countries, including the UK (EFSA 2008a). The lower bound mean levels for these parameters were $2.78,12.8,23.7$, and $30.0 \mu^{~ ~ k g^{-1}}$, respectively (EFSA 2008b). We found in 2008 and 2009 higher values for these parameters, which amounted to respectively $5.33,20.8,33.8$, and $40.9 \mu \mathrm{g} \mathrm{kg}^{-1}$. Our sampling protocol was targeted at supplements with relatively high PAH levels, whereas the data submitted to EFSA were obtained by both targeted and random sampling. Mean PAH4 levels in food supplements came second in the EFSA Opinion after levels in dried tea samples, which showed a lower bound mean of $42.7 \mu \mathrm{g} \mathrm{kg}^{-1}$ PAH4 (EFSA 2008b). The highest individual PAH level reported for foods tested for all 15 SCF priority PAH was $1064 \mu \mathrm{g} \mathrm{kg}^{-1}$ benz[a]anthracene in tinned sprats. According to EFSA this value was possibly an aberration, however. The second and third highest individual PAH levels $\left(690 \mu \mathrm{g} \mathrm{kg}^{-1}\right.$ of benzo[b]fluoranthene and $590 \mu \mathrm{g}$ $\mathrm{kg}^{-1}$ of chrysene, respectively) were found in food supplements (EFSA 2008b). In the category of supplements, a black tea supplement showed the highest combined PAH concentrations and a supplement with spirulina and one with propolis extract showed the second and third highest concentrations, respectively (EFSA 2008a). In our study, the highest and second highest individual PAH levels were found in food supplements with resveratrol amounting to 503 and $474 \mu \mathrm{g} \mathrm{kg}^{-1}$ benzo[c]fluorene, respectively. EFSA received data on benzo[c]fluorene in only 


\section{1}

24 food supplements and 9 (37.5\%) of these contained this PAH, with a maximum of $9.6 \mathrm{\mu g} \mathrm{kg}^{-1}$ (EFSA 2008b). We tested 333 supplements for benzo[c]fluorene and $70(21 \%)$ contained this $\mathrm{PAH}$, with a maximum of $503 \mu \mathrm{g}$ $\mathrm{kg}^{-1}$ (Table 7).

With respect to using lower or upper bound PAH levels, EFSA concluded that overall there was a very limited impact of using the lower or the upper bound, but the choice for the upper bound would represent a small but real overestimation (EFSA 2008b). In the current study, we chose to report the lower bound PAH levels in order to avoid overestimation. EFSA calculated the lower bound by replacing values below the LOD by 0 . However, conflicting information was provided by EFSA in the Opinion on PAH in food on how values reported by Member States to be below the $L O Q$ were treated. The first method provided was replacing values below the $L O Q$ by 0 , and a second was replacing values below the $L O Q$ by the value for the LOD for each individual PAH (EFSA 2008b). In the current study, we calculated the lower bound PAH levels by replacing both the values below the LOD and the LOQ by 0 . This approach is therefore likely to result in an underestimation of actual PAH levels in food supplements.

\section{Sources of PAH in botanical materials}

Danyi et al. (2009) briefly addressed possible mechanisms by which botanical materials could become contaminated with PAH. It was concluded that absorption of PAH by plant roots from soil was limited and that the level of contamination of botanical material with environmental PAH deposited from the atmosphere, depended on plant morphology. Moreover, the major source of PAH in seaweed or other marine botanicals was accidental marine pollution such as oil spills. Interestingly, drying practices during manufacturing were deemed a major source of contamination (Danyi et al. 2009 and references therein). This is in agreement with the JECFA recommendation that contact of food with combustion gases should be minimized (JECFA 2006; Codex Alimentarius 2009). Direct drying procedures that use combustion gasses as the drying gas that comes in contact with the foods increased PAH contamination by 3- to 10-fold dependent on the fuel used (Codex Alimentarius 2009). The Codex Alimentarius code of practice for the reduction of contamination of food with PAH from smoking and direct drying processes advised therefore against the use of diesel oil, rubber, tyres or waste oil as fuel (Codex Alimentarius 2009). Furthermore, relatively low PAH levels of botanical materials (for example resulting from atmospheric deposition) may become magnified when these materials are further subjected to concentration 
steps that also concentrate $\mathrm{PAH}$, as was suggested to occur in the production process of natural vitamin $\mathrm{E}$ by Horrobin and Manku (1997).

\section{Margins of exposure for dietary PAH in the EU}

EFSA calculated in their Opinion on PAH in food margins of exposure (MOEs) for benzo[a]pyrene, PAH2, PAH4, and PAH8 by dividing the lowest Benchmark Dose Lower Confidence Limit associated with an extra $10 \%$ cancer risk relative to background incidence (BMDL10) by the estimated mean exposure to these PAH in the EU (EFSA 2008b). From the estimated mean dietary exposure to PAH4 in the EU of $19.5 \mathrm{ng}$ per kg body weight per day (ng $\mathrm{kg} \mathrm{bw}^{-1}$ day $^{-1}$ ) and the lowest BMDL10 for PAH4 identified by EFSA of $0.34 \mathrm{mg} \mathrm{kg} \mathrm{bw}^{-1}$ day $^{-1}$, an MOE of 17,500 applicable to consumers at average exposure levels was calculated (EFSA 2008b). Similarly, for the $97.5^{\text {th }}$ percentile of the estimated dietary exposure to PAH4 in the EU of $34.5 \mathrm{ng} \mathrm{kg} \mathrm{bw}^{-1}$ day $^{-1}$, an MOE of 9900 applicable to these high-level consumers was derived. Furthermore, MOEs were calculated using PAH8 as marker for carcinogenic $\mathrm{PAH}$ in food, which amounted to an MOE of 17,000 for consumers at average exposure levels and an MOE of 9600 for consumers at high exposure levels (EFSA 2008b). EFSA concluded that the MOEs calculated for average consumers indicated a low concern for consumer health, but that the MOEs for high level consumers are close to or less than 10,000, which indicates a potential concern for consumer health and a possible need for risk management action (EFSA 2005; EFSA 2008b).

\section{Margins of exposure for PAH in food supplements with high PAH levels}

In the current study, the highest estimated daily exposure to PAH4 of $705 \mathrm{ng}$ was calculated for a multi-ingredient botanical food supplement with resveratrol (No. 13 from Table 9). Assuming a body weight of $60 \mathrm{~kg}$, the exposure to PAH4 with this supplement used at the maximum recommended dose level would amount to $11.7 \mathrm{ng} \mathrm{kg} \mathrm{bw}{ }^{-1}$ day $^{-1}$. From this value and the lowest BMDL10 value for PAH4 identified as acceptable by EFSA of $0.34 \mathrm{mg} \mathrm{kg}$ bw $^{-1}$ day $^{-1}$ (EFSA 2008b), an MOE of 28,900 (rounded off to the nearest 100) was calculated. Similarly, MOEs calculated for the daily exposure to benzo[a]pyrene, PAH2, and PAH8(-IcP) from this supplement at the recommended dose level by using BMDL10 values of respectively $0.07,0.17$, and $0.49 \mathrm{mg} \mathrm{kg} \mathrm{bw}^{-1}$ day $^{-1}$ (EFSA 2008b), were 24,600 for benzo[a]pyrene, 25,500 for PAH2, and 31,500 for PAH8(-IcP). Although these MOEs were higher than 10,000 , the estimated daily benzo[a]pyrene intake of $2.85 \mathrm{ng} \mathrm{kg} \mathrm{bw}^{-1} \mathrm{day}^{-1}$ with this supplement 
at the recommended dose level exceeded the virtual safe dose (VSD) for all dietary PAH expressed as $0.5 \mathrm{ng} \mathrm{kg}$ bw $^{-1}$ day $^{-1}$ of benzo[a]pyrene established in 2001 by the Dutch National Institute for Public Health and the Environment (RIVM) using benzo[a]pyrene as an indicator for the occurrence and carcinogenic potency of dietary PAH. The VSD was based on a rat study with coal tar mixture administered by oral gavage (Kroese et al. 2001). The estimated PAH4 intake from this particular supplement would amount to $60 \%$ of the estimated mean dietary exposure to PAH4 in the EU calculated by EFSA and $34 \%$ of the $97.5^{\text {th }}$ percentile of estimated dietary exposure to PAH4 in the EU derived by EFSA (EFSA 2008b).

Relatively high estimated PAH intakes with individual food supplements containing high PAH levels have been reported in other studies as well (FSA 2005; Moret et al. 2010). In the FSA study (FSA 2005), a spirulina supplement used at the maximum recommended dose level by a $60 \mathrm{~kg}$ adult would provide $57.4 \mathrm{ng} \mathrm{kg} \mathrm{bw}^{-1}$ day $^{-1}$ of PAH4 and $68.7 \mathrm{ng} \mathrm{kg} \mathrm{bw}^{-1}$ day $^{-1}$ of PAH8, which would result in MOEs of 5900 and 7100, respectively, calculated by using BMDL10 values of $0.34 \mathrm{mg} \mathrm{kg} \mathrm{bw}^{-1}$ day $^{-1}$ for PAH4 and of $0.49 \mathrm{mg} \mathrm{kg} \mathrm{bw}^{-1}$ day $^{-1}$ for PAH8. In a study on PAH in propolis on the Italian market, high estimated PAH8 intakes were derived for several propolis products (Moret et al. 2010). For a sample of raw propolis, a daily PAH8 intake estimate of $46.7 \mathrm{ng} \mathrm{kg} \mathrm{bw}^{-1}$ day $^{-1}$ was reported for a $60 \mathrm{~kg}$ adult by assuming a daily dosage of $200 \mathrm{mg}$ (Moret et al. 2010). From the individual PAH concentrations reported for this sample, an estimated daily PAH4 intake level of $32.6 \mathrm{ng} \mathrm{kg} \mathrm{bw}^{-1}$ day $^{-1}$ could also be calculated, assuming a $60 \mathrm{~kg}$ adult consuming $200 \mathrm{mg}$ of raw propolis per day. For these estimated PAH4 and PAH8 intake levels, MOE values of 10,400 and 10,500, respectively, could be calculated. However, the daily dosage used to estimate PAH4 and PAH8 exposure was rather low. Our study included a propolis supplement with a maximum recommended dose level of $2 \mathrm{~g}$ per day (No. 1 of Table 6 ). Furthermore, recommended dosages of $3 \mathrm{~g}$ propolis per day were also found on the Internet (Moret et al. 2010). When a recommended dose level of 2 $\mathrm{g}$ would be assumed for this particular raw propolis sample, these MOEs would be tenfold lower thus resulting in MOEs below 10,000 (Moret et al. 2010).

\section{Exposure to PAH from food supplements vs. dietary exposure}

EFSA presented data on the contributions of individual food categories to PAH exposure of consumers of these foods. These contributions were calculated by first collecting for each food category the mean consumption of consumers only in each Member State and then by multiplying the median of these by the mean 
contamination (EFSA 2008b). The contributions thus obtained ranged from $20 \mathrm{ng}$ PAH4 per day for cheese up to $289 \mathrm{ng}$ per day for seafood and seafood products (EFSA 2008b). In our 2008 and 2009 survey, the estimated daily PAH4 intakes at the recommended dose level of 20 supplements with relatively high PAH levels ranged from 38 up to $705 \mathrm{ng}$ per day (Table 9). Use at the recommended dose level of four of these supplements would result in $\mathrm{PAH} 4$ exposure exceeding the highest contribution of a food category to $\mathrm{PAH} 4$ exposure of consumers (EFSA 2008b). This shows that individual food supplements can contribute significantly to the daily PAH exposure of consumers. Collectively, the PAH intake from food supplements will be less substantial however. From the lower bound estimate of the mean PAH4 level of $33.8 \mu_{\mathrm{g} \mathrm{kg}}^{-1}$ found in our 2008 and 2009 survey and an assumed daily dosage of $1 \mathrm{~g}$, a daily PAH4 intake of $34 \mathrm{ng}$ per day, equivalent to $0.6 \mathrm{ng} \mathrm{kg} \mathrm{bw}^{-1}$ day $^{-1}$ for a 60 $\mathrm{kg}$ adult, could be estimated. This intake estimate of PAH4 would amount to $2.9 \%$ of the average dietary exposure to PAH4 across the EU and $1.6 \%$ of the high level dietary exposure (EFSA 2008b). Furthermore, the mean PAH4 intake of $34 \mathrm{ng}$ per day estimated in our study for food supplements (mainly with botanical ingredients) was comparable to contributions from cheese (20 ng PAH4 per day), alcoholic beverages ( $25 \mathrm{ng}$ PAH4 per day) and sugar and sugar products including chocolate (25 ng PAH4 per day) to PAH4 exposure of consumers (EFSA 2008b).

\section{Conclusion}

From 2003 up to and including 2007, benzo[a]pyrene was present above the LOQ in 553 (44\%) of 1258 supplements and the lower bound mean benzo[a]pyrene level was $3.37 \mu \mathrm{g} \mathrm{kg}^{-1}$. In the 2008 and 2009 survey, $210(63 \%)$ of 333 food supplements showed benzo[a]pyrene levels above the LOQ and the lower bound mean

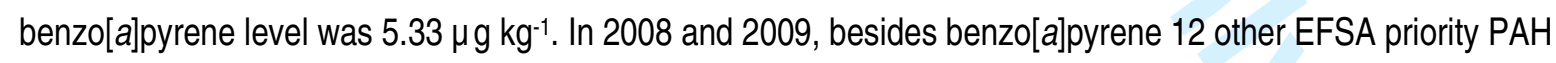
were also determined and the lower bound mean PAH2, PAH4 and PAH8(-IcP) levels were 20.8, $33.8 \mu \mathrm{g} \mathrm{kg}^{-1}$ and $40.9 \mathrm{\mu g} \mathrm{kg}^{-1}$, respectively. In this period, mono-ingredient supplements with resveratrol, St. John's wort, Ginkgo biloba and propolis showed the highest mean PAH levels. Prior to 2008, the highest mean benzo[a]pyrene levels were found in mono-ingredient supplements with dong quai, green tea, Ginkgo biloba, St. John's wort, valerian, propolis and pollen, and in natural vitamin E supplements with expiry dates before 2007. Because all subcategories of food supplements in the current study included supplements that did not contain 
1

2

3

4

5

6

7

8

9

10

11

12

13

14

15

16

17

18

19

20

21

22

23

24

25

26

27

28

29

30

31

32

33

34

35

36

37

38

39

40

41

42

43

44

45

46

47

48

49

50

51

52

53

54

55

56

57

58

59

60

quantifiable or relatively low levels of PAH4, it is concluded that contamination of food supplements with PAH is avoidable.

With respect to intake estimates for PAH4 from food supplements, it can be concluded that use at maximum recommended dose levels of individual food supplements, especially those with botanicals or propolis, can contribute significantly to PAH exposure, whereas collectively, PAH intake resulting from food supplement use will be at the lower end of the range of contributions of main food groups to PAH exposure of consumers of these foods. Efforts aiming at regular control and reduction of PAH levels in food supplements may prove a way forward to further reduce the intake of these genotoxic carcinogens from food. 


\section{References}

Codex Alimentarius. 2009. Code of Practice for the Reduction of Contamination of Food with Polycyclic Aromatic Hydrocarbons (PAH) from Smoking and Direct Drying Processes (CAC/RCP 68) [Internet]. Rome: Joint FAO/WHO Food Standards Programme; [cited 2010 August 19]. Available from: www.codexalimentarius.net/web/more_info.jsp?id_sta=11257

Danyi S, Brose F, Brasseur C, Schneider YJ, Larondelle Y, Pussemier L, Robbens J, De SS, Maghuin-Rogister G, Scippo ML. 2009. Analysis of EU priority polycyclic aromatic hydrocarbons in food supplements using high performance liquid chromatography coupled to an ultraviolet, diode array or fluorescence detector. Anal Chim Acta. 633(2): 293-299.

Dobrinas S, Birghila S, Coatu V. 2008. Assessment of polycyclic aromatic hydrocarbons in honey and propolis produced from various flowering trees and plants in Romania. J Food Comp Anal. 21(1): 71-77.

EFSA. 2005. Opinion of the Scientific Committee on a request from EFSA related to a harmonised approach for risk assessment of substances which are both genotoxic and carcinogenic. EFSA J. 282: 1-31.

EFSA. 2008a. Findings of the EFSA Data Collection on a Request from the European Commission on Polycyclic Aromatic Hydrocarbons in Food (revision 1). First issued on 29 June 2007 and revised on 31 July 2008 [Internet]. Parma: European Food Safety Authority; [cited 2010 August 19]. Available from: www.efsa.europa.eu/EFSA/Report/datex_report_update_en.pdf?ssbinary=true

EFSA. 2008b. Scientific Opinion of the Panel on Contaminants in the Food Chain on a request from the European Commission on Polycyclic Aromatic Hydrocarbons in Food. EFSA J. 724: 1-114.

EFSA. 2009. EFSA Scientific Committee; Guidance on safety assessment of botanicals and botanical preparations intended for use as ingredients in food supplements, on request of EFSA. EFSA J. 7(9): 1249-1267.

European Commission. 2005. Commission Recommendation of 4 February 2005 on the further investigation into the levels of polycyclic aromatic hydrocarbons in certain foods. Off J Eur Union. L 34: 43-45. 
European Commission. 2006. Commission Regulation (EC) No 1881/2006 of 19 December 2006 setting maximum levels for certain contaminants in foodstuffs. Off J Eur Union. L 364: 5-24.

FSA. 2005. PAHs in dietary supplements; Food Survey Information Sheet 86/05 [Internet]. London: Food Standards Agency. [cited 2010 August 19]. Available from: www.food.gov.uk/multimedia/pdfs/fsis8605.pdf

Horrobin DF, Manku MS. 1997. Tocopherols; United States Patent Number 5,635,189.

JECFA. 2006. Safety evaluation of certain contaminants; WHO Food Additives Series, No. 55. Chapter on Polycyclic aromatic hydrocarbons; p. 563-743. Geneva: World Health Organization. Available from: http://whqlibdoc.who.int/publications/2006/9241660554_PAH_eng.pdf

Kroese ED, Muller JJA, Mohn GR, Dortant PM, Wester PW. 2001. Tumourigenic effects in Wistar rats orally administered benzo[a]pyrene for two years (gavage studies); Implications for human cancer risks associated with oral exposure to polycyclic aromatic hydrocarbons. Bilthoven: National Institute of Public Health and the Environment (RIVM). Available from: www.rivm.nl/bibliotheek/rapporten/658603010.pdf

Moret S, Purcaro G, Conte LS. 2010. Polycyclic aromatic hydrocarbons (PAHs) levels in propolis and propolisbased dietary supplements from the Italian market. Food Chem. 122(1): 333-338.

SCF. 2002. Opinion of the Scientific Committee on Food on the risks to human health of Polycyclic Aromatic Hydrocarbons in food [Internet]. Brussels: European Commission, Health \& Consumer Protection Directorate-General; [cited 2010 August 19]. Available from: http://ec.europa.eu/food/fs/sc/scf/out153_en.pdf

Thompson M, Wood R. 1995. International Union of Pure and Applied Chemistry; Harmonized guidelines for internal quality control in analytical chemistry laboratories (Technical Report). Pure Appl Chem. 67(4):649666.

van der Wielen JC, Jansen JT, Martena MJ, De Groot HN, In 't Veld PH. 2006. Determination of the level of benzo[a]pyrene in fatty foods and food supplements. Food Addit Contam. 23(7):709-714. 
van Stijn F, Kerkhoff MA, Vandeginste BG. 1996. Determination of polycyclic aromatic hydrocarbons in edible oils and fats by on-line donor-acceptor complex chromatography and high-performance liquid chromatography with fluorescence detection. J Chromatogr A. 750(1-2):263-273.

VWS. 2005. Regeling van de Minister van Volksgezondheid, Welzijn en Sport van 22 november 2005, nr. VGP/VL 2636893, houdende wijziging van de Warenwetregeling Verontreinigingen in levensmiddelen. Staatscourant 2005, November 28, 231.

Yang Y, Dong X, Jin M, Ren Q. 2008. Rapid determination of polycyclic aromatic hydrocarbons in natural tocopherols by high-performance liquid chromatography with fluorescence detection. Food Chem. 110(1): 226-232. 


\section{Legend}

Figure 1. Minimum, median ( $\downarrow)$ and maximum levels of PAH4 $\left(\mu \mathrm{g} \mathrm{kg}^{-1}\right)$ in different categories of food supplements sampled in 2008 and 2009. 
$\begin{array}{ll}1 & \\ 2 & \\ 3 & \text { Figure 1 } \\ 4 & \end{array}$

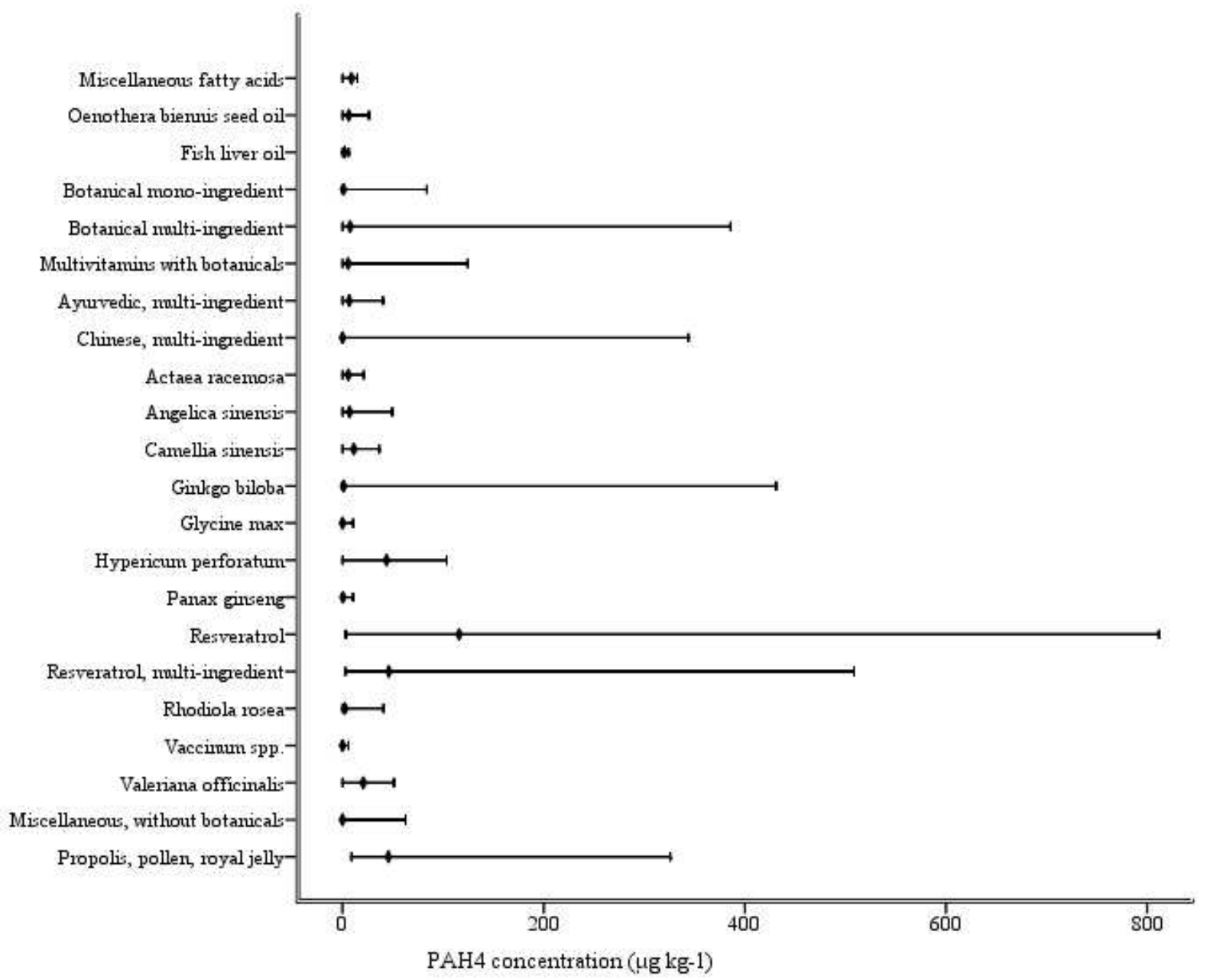


Tables

$\underline{\text { Revision } 1}$

Monitoring of Polycyclic Aromatic Hydrocarbons (PAH) in food supplements with botanicals and other ingredients on the Dutch market 
Table 1. Overview of lists of priority PAH put forward by SCF, JECFA and EFSA and the priority PAH proposed by EFSA as indicators for the occurrence and toxicity of PAH in food.

\begin{tabular}{|c|c|c|c|c|c|c|c|}
\hline \multicolumn{2}{|l|}{$\mathrm{PAH}$} & \multicolumn{3}{|c|}{ Priority PAH } & \multicolumn{3}{|c|}{ EFSA indicator groups ${ }^{c}$} \\
\hline & & $\mathrm{SCF}^{\mathrm{a}}$ & JECFA $^{b}$ & $\mathrm{EFSA}^{\mathrm{c}}$ & $\mathrm{PAH} 2$ & $\mathrm{PAH} 4$ & PAH8 \\
\hline 1. benz[a]anthracene & $\mathrm{BaA}$ & $\mathrm{x}$ & $\mathrm{x}$ & $\mathrm{x}$ & & $\mathrm{x}$ & $\mathrm{x}$ \\
\hline 2. benzo[b]fluoranthene & $\mathrm{BbF}$ & $x$ & $x$ & $x$ & & $x$ & $x$ \\
\hline 3. benzo[j]fluoranthene & $\mathrm{BjF}$ & $x$ & $x$ & $x$ & & & \\
\hline 4. benzo[k]fluoranthene, & BkF & $x$ & $x$ & $x$ & & & $x$ \\
\hline 5. benzo[ghi]perylene & $\mathrm{BgP}$ & $x$ & - & $x$ & & & $x$ \\
\hline 6. benzo[a]pyrene & $\mathrm{BaP}$ & $x$ & $x$ & $x$ & $x$ & $x$ & $x$ \\
\hline 7. chrysene & $\mathrm{CHR}$ & $x$ & $x$ & $x$ & $x$ & $x$ & $x$ \\
\hline 8. cyclopenta[cd]pyrene & CPP & $x$ & - & $x$ & & & \\
\hline 9. dibenz[a,h]anthracene & DhA & $x$ & $x$ & $x$ & & & $x$ \\
\hline 10. dibenzo[a,e]pyrene & $\mathrm{DeP}$ & $\mathrm{x}$ & $\mathrm{x}$ & $\mathrm{x}$ & & & \\
\hline 11. dibenzo[a,h]pyrene & $\mathrm{DhP}$ & $\mathrm{x}$ & $\mathrm{x}$ & $\mathrm{x}$ & & & \\
\hline 12. dibenzo[a,i]pyrene & DiP & $x$ & $\mathrm{x}$ & $\mathrm{x}$ & & & \\
\hline 13. dibenzo[a,/]pyrene & DIP & $\mathrm{x}$ & $x$ & $\mathrm{x}$ & & & \\
\hline 14. indeno $[1,2,3-c d]$ pyrene & $\mathrm{ICP}$ & $x$ & $x$ & $x$ & & & $x$ \\
\hline 15. 5-methylchrysene & $5 \mathrm{MC}$ & $\mathrm{x}$ & $x$ & $x$ & & & \\
\hline 16. benzo[c]fluorene & $\mathrm{BcL}$ & - & +1 & $x$ & & & \\
\hline
\end{tabular}

Sources: a SCF (2002), bJECFA (2006), ' EFSA (2008ㅁ). 
Table 2. HPLC Quaternary Pump gradient for the analysis of $13 \mathrm{PAH}$.

\begin{tabular}{ccccc}
\hline Time $(\mathrm{min})$ & $\mathrm{H}_{2} \mathrm{O}(\%)$ & Acetonitril $(\%)$ & Ethylacetate $(\%)$ & Flow $\left(\mathrm{ml} \mathrm{min}^{-1}\right)$ \\
\hline 0.00 & 15 & 85 & 0 & 0.40 \\
15.00 & 15 & 85 & 0 & 1.00 \\
26.00 & 15 & 85 & 0 & 1.00 \\
35.00 & 5 & 90 & 5 & 1.00 \\
45.00 & 5 & 80 & 15 & 1.00 \\
50.00 & 5 & 80 & 15 & 1.00 \\
55.00 & 0 & 30 & 70 & 1.00 \\
70.00 & 0 & 30 & 70 & 1.00 \\
73.00 & 15 & 85 & 0 & 1.00 \\
75.00 & 15 & 85 & 0 & 1.00 \\
80.00 & 15 & 85 & 0 & 0.40 \\
\hline
\end{tabular}


Table 3: Variable wavelength settings for the analysis of 13 EFSA priority PAH

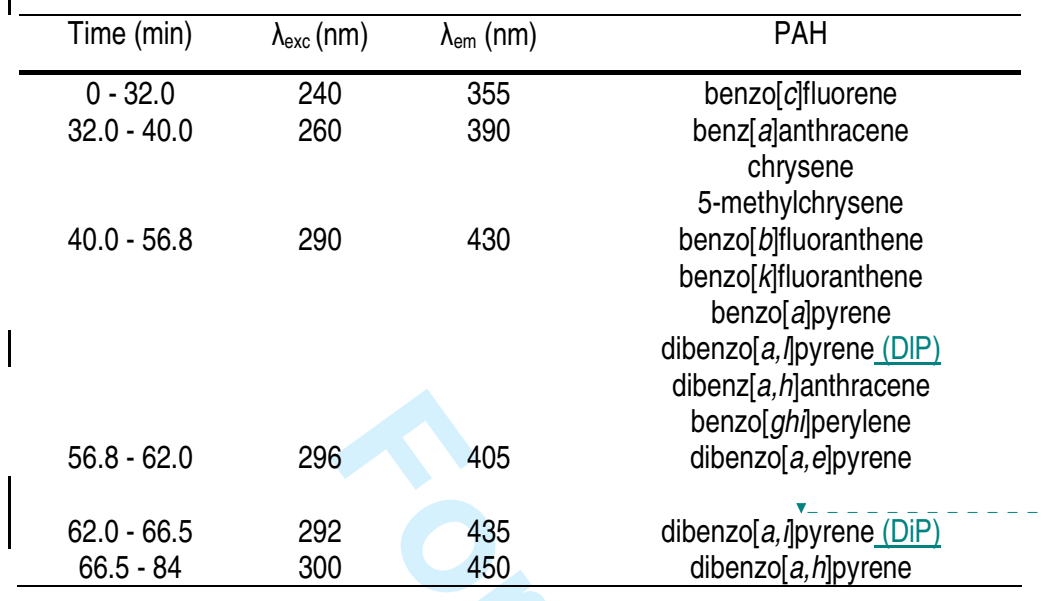

Deleted: benzo[b]chrysene 
Table 4. Validation data on the method for the determination PAH in botanical materials.

\begin{tabular}{lccccccc}
\hline PAH & $\begin{array}{c}\mathrm{LOD} \\
\left(\mu \mathrm{g} \mathrm{kg}^{-1}\right)\end{array}$ & $\begin{array}{c}\mathrm{LOQ} \\
\left(\mu \mathrm{g} \mathrm{kg}^{-1}\right)\end{array}$ & $\begin{array}{c}\mathrm{Rec} . \\
(\%)\end{array}$ & $\begin{array}{c}\text { True. } \\
(\%)\end{array}$ & $\begin{array}{c}\mathrm{RSD}_{\mathrm{r}} \\
(\%)\end{array}$ & $\begin{array}{c}\mathrm{R}_{\mathrm{L}} \\
\left(\mu \mathrm{g} \mathrm{kg}^{-1}\right)\end{array}$ & $\begin{array}{c}\mathrm{U} \\
(\%)\end{array}$ \\
\hline benz[a]anthracene & 1.76 & 3.53 & 102 & 100 & 8 & 1.4 & 10 \\
benzo[b]fluoranthene & 0.76 & 1.53 & 99 & 99 & 2 & 0.9 & 7 \\
benzo[j]luoranthene & - & - & - & - & - & - & - \\
benzo[k]fluoranthene & 0.26 & 0.53 & 107 & 100 & 9 & 2.5 & 18 \\
benzo[ghi]perylene & 0.95 & 1.90 & 109 & 104 & 2 & 0.7 & 10 \\
benzo[a]pyrene & 0.26 & 0.52 & 111 & 111 & 2 & 0.5 & 23 \\
chrysene & 0.39 & 0.79 & 100 & 102 & 6 & 0.9 & 8 \\
cyclopenta[cd]pyrene & - & - & - & - & - & - & - \\
dibenz[a,h]anthracene & 1.00 & 2.01 & 100 & 96 & 3 & 0.5 & 10 \\
dibenzo[a,e]pyrene & 0.67 & 1.34 & 100 & 103 & 4 & 2.1 & 17 \\
dibenzo[a,h]pyrene & 0.52 & 1.04 & 98 & 121 & 27 & 2.9 & 47 \\
dibenzo[a,i]pyrene & 0.33 & 0.65 & 114 & 102 & 3 & 1.2 & 9 \\
dibenzo[a,Ijpyrene & 0.40 & 0.79 & 112 & 113 & 2 & 1.2 & 27 \\
indeno[1,2,3-cd]pyrene & - & - & - & - & - & - & - \\
5-methylchrysene & 0.35 & 0.69 & 96 & 98 & 8 & 1.5 & 12 \\
benzo[c]fluorene & 0.58 & 1.16 & 110 & 114 & 2 & 2.4 & 32 \\
\hline Nos:
\end{tabular}

Notes:

LOD: Limit of Detection.

LOQ: Limit of Quantification.

Rec.: Recovery.

True:: Trueness.

RSD: Relative standard deviation calculated from results generated under repeatability conditions.

RL: Reproducibility, within laboratory.

U: $\quad$ Expanded uncertainty. 
Table 5. Descriptive statistics for lower bound a benzo[a]pyrene (BaP) levels in various supplement groups sampled in 2003 up to and including 2007 and the percentage of supplements with BaP levels above the LOD, 1, 2, 5 , or $10 \mu \mathrm{g} \mathrm{kg}^{-1}$.

\begin{tabular}{|c|c|c|c|c|c|c|c|c|c|c|c|c|}
\hline \multicolumn{2}{|c|}{ Supplement characteristics } & \multirow[t]{2}{*}{$\mathrm{N}$} & \multicolumn{5}{|c|}{ Supplements (\%) above limit for $\mathrm{BaP}\left(\mu \mathrm{g} \mathrm{kg}^{-1}\right)$} & \multicolumn{5}{|c|}{ BaP concentration $\left(\mu \mathrm{g} \mathrm{kg}^{-1}\right)$} \\
\hline Category & Type/ ingredient ${ }^{b}$ & & $>\mathrm{LOQ}$ & $>1$ & $>2$ & $>5$ & $>10$ & Median & Mean & $\mathrm{P} 90$ & P95 & Max \\
\hline \multicolumn{2}{|c|}{ Fatty acids Mono-ingredient } & 15 & 20 & 13 & 7 & 7 & 0 & 0 & 0.71 & 1.20 & 3.50 & 8.41 \\
\hline & Multi-ingredient & 29 & 24 & 14 & 7 & 3 & 0 & 0 & 0.49 & 1.38 & 2.81 & 5.58 \\
\hline & Conjugated linoleic acid & 9 & 33 & 33 & 22 & 11 & 11 & - & 1.66 & - & - & 11.7 \\
\hline & Borago officinalis (borage) seed oil & 7 & 71 & 29 & 0 & 0 & 0 & - & 0.61 & - & - & 1.11 \\
\hline & Linum usitatissimum (flax) seed oil & 6 & 0 & 0 & 0 & 0 & 0 & - & 0 & - & - & 0 \\
\hline & Fish oil, shark liver oil & 82 & 20 & 6 & 1 & 0 & 0 & 0 & 0.19 & 0.79 & 1.01 & 2.17 \\
\hline & \multicolumn{12}{|l|}{ Oenothera biennis (evening primrose) seed } \\
\hline & oil & 47 & 23 & 17 & 6 & 4 & 2 & 0 & 0.75 & 1.28 & 3.84 & 13.9 \\
\hline & Triticum sp. (wheat) germ oil & 21 & 14 & 5 & 5 & 5 & 0 & 0 & 0.51 & 0.60 & 1.00 & 9.12 \\
\hline \multirow[t]{23}{*}{ Botanical } & Mono-ingredient & 39 & 41 & 26 & 10 & 0 & 0 & 0 & 0.61 & 1.86 & 2.35 & 3.73 \\
\hline & Multi-ingredient & 128 & 58 & 51 & 38 & 20 & 8 & 1.10 & 2.86 & 9.10 & 11.62 & 33.5 \\
\hline & Multivitamins with and without botanicals & 125 & 22 & 13 & 6 & 2 & 1 & 0 & 0.72 & 1.10 & 2.33 & 43.4 \\
\hline & Ayurvedic, multi-ingredient & 11 & 55 & 55 & 18 & 0 & 0 & 1.06 & 1.23 & 3.21 & 3.89 & 4.56 \\
\hline & Chinese, mono-ingredient & 8 & 38 & 38 & 25 & 25 & 0 & - & 2.41 & - & - & 9.59 \\
\hline & Chinese, multi-ingredient & 10 & 80 & 80 & 60 & 20 & 0 & 3.16 & 2.92 & 5.35 & 5.81 & 6.26 \\
\hline & Actaea racemosa ${ }^{\circ}$ (black cohosh) & 4 & 100 & 75 & 75 & 50 & 25 & - & 6.29 & - & - & 12.5 \\
\hline & Allium sativum (garlic) & 24 & 21 & 13 & 8 & 0 & 0 & 0 & 0.50 & 1.56 & 3.34 & 4.92 \\
\hline & Aloe vera & 4 & 25 & 25 & 0 & 0 & 0 & - & 0.34 & - & - & 1.35 \\
\hline & Angelica sinensis (dong quai) & 12 & 83 & 67 & 50 & 42 & 33 & 2.11 & 8.12 & 24.6 & 24.7 & 24.9 \\
\hline & Camellia sinensis (green tea) & 18 & 83 & 78 & 72 & 56 & 44 & 8.13 & 26.6 & 83.1 & 135 & 145 \\
\hline & Camellia sinensis (pu erh tea) & 3 & 100 & 100 & 100 & 100 & 67 & - & 11.6 & - & - & 13.8 \\
\hline & Echinacea spp. (coneflower) & 4 & 50 & 0 & 0 & 0 & 0 & . & 0.31 & - & - & 0.61 \\
\hline & \multicolumn{12}{|l|}{ Eleutherococcus senticosus (Siberian } \\
\hline & ginseng) & 8 & 63 & 38 & 25 & 25 & 13 & - & 5.29 & - & - & 34.2 \\
\hline & Ginkgo biloba & 65 & 77 & 69 & 55 & 32 & 25 & 2.73 & 7.48 & 20.2 & 31.3 & 64.4 \\
\hline & Glycine max (soy) protein, isoflavones & 12 & 17 & 8 & 0 & 0 & 0 & 0 & 0.21 & 0.90 & 1.23 & 1.50 \\
\hline & Hypericum perforatum (St. John's wort) & 38 & 82 & 63 & 39 & 21 & 11 & 1.60 & 9.87 & 15.7 & 49.5 & 144 \\
\hline & Panax ginseng (ginseng) & 55 & 58 & 45 & 33 & 13 & 5 & 0.84 & 2.86 & 7.32 & 9.22 & 38.2 \\
\hline & Paullinia cupana (guarana) & 8 & 50 & 38 & 0 & 0 & 0 & - & 0.63 & - & - & 1.60 \\
\hline & Silybum marianum $\mathrm{d}$ (milk thistle) & 8 & 50 & 38 & 38 & 13 & 13 & - & 2.37 & - & - & 11.6 \\
\hline & Spirulina & 8 & 38 & 38 & 13 & 0 & 0 & - & 0.69 & - & - & 2.44 \\
\hline & Uncaria tomentosa (cat's claw) & 5 & 20 & 0 & 0 & 0 & 0 & - & 0.14 & - & - & 0.70 \\
\hline
\end{tabular}




\section{Page 33 of 40}

Food Additives and Contaminants

\begin{tabular}{|c|c|c|c|c|c|c|c|c|c|c|c|c|}
\hline & Vaccinum spp. (cranberry) & 5 & 0 & 0 & 0 & 0 & 0 & - & 0 & - & - & 0 \\
\hline & Valeriana officinalis (valerian) & 30 & 73 & 60 & 50 & 37 & 17 & 1.90 & 7.87 & 22.2 & 38.4 & 52.6 \\
\hline & Zingiber officinale (ginger) & 16 & 81 & 69 & 50 & 13 & 0 & 2.00 & 2.30 & 4.74 & 5.52 & 6.88 \\
\hline \multirow[t]{10}{*}{ Other } & Mono-ingredient without botanicals & 18 & 6 & 6 & 6 & 0 & 0 & 0 & 0.28 & 0 & 0.74 & 4.95 \\
\hline & Coenzyme Q10 & 15 & 20 & 7 & 0 & 0 & 0 & 0 & 0.23 & 0.74 & 1.15 & 1.96 \\
\hline & Carotenoids & 22 & 32 & 23 & 14 & 0 & 0 & 0 & 0.50 & 2.02 & 2.10 & 2.20 \\
\hline & Lecithin & 16 & 0 & 0 & 0 & 0 & 0 & 0 & 0 & 0 & 0 & 0 \\
\hline & Propolis, bee pollen & 10 & 80 & 70 & 60 & 30 & 30 & 4.35 & 6.53 & 16.4 & 17.6 & 18.9 \\
\hline & Vitamin A or D & 5 & 0 & 0 & 0 & 0 & 0 & - & 0 & - & - & 0 \\
\hline & Vitamin C & 20 & 5 & 0 & 0 & 0 & 0 & 0 & 0.05 & 0 & 0.05 & 0.90 \\
\hline & Vitamin E with expiry date before 2007 & 163 & 57 & 52 & 48 & 42 & 38 & 1.55 & 14.9 & 44.1 & 63.3 & 207 \\
\hline & Vitamin E with expiry date from 2007 & 37 & 5 & 5 & 0 & 0 & 0 & 0 & 0.06 & 0 & 0.21 & 1.16 \\
\hline & Unknown & 88 & 56 & 44 & 35 & 16 & 11 & 0.75 & 4.07 & 12.1 & 15.5 & 63.4 \\
\hline
\end{tabular}

\section{Notes:}

a For a lower bound estimate, values for samples with PAH levels below LOD or LOQ were replaced by 0 .

b When one ingredient is listed, this substance generally represents the only active ingredient in this group.

c Syn. Cimicifuga racemosa.

d Syn. Carduus marianus. 
Table 6. Examples of daily intake levels of benzo[a]pyrene $(\mathrm{BaP})$ with supplements, when used according to the recommended use level as stated on the label, sampled in 2003 up to and including 2007.

\begin{tabular}{lccccc}
\hline Supplement type & $\mathrm{BaP}\left(\mu \mathrm{g} \mathrm{kg}^{-1}\right)$ & Year of analysis & $\begin{array}{c}\text { Maximum dose } \\
(\text { No. of units) }\end{array}$ & Unit weight $(\mathrm{g})$ & $\begin{array}{c}\text { Intake BaP } \\
\left.\text { (ng day }{ }^{-1}\right)\end{array}$ \\
\hline 1. Bee propolis & 18.9 & 2003 & 4 & 0.504 & 38.1 \\
2. Ginkgo biloba & 64.4 & 2003 & 1 & 0.235 & 15.1 \\
3. Green tea & 29.5 & 2004 & 4 & 0.385 & 45.4 \\
4. Green tea & 145 & 2004 & 4 & 0.388 & 225 \\
5. Green tea & 39.3 & 2003 & 2 & 0.426 & 33.5 \\
6. Multi-ingredient botanical & 23 & 2003 & 2 & 1.21 & 55.6 \\
7. Multivitamin with botanicals & 43.4 & 2003 & 3 & 1.76 & 229 \\
8. Natural vitamin E & 63.4 & 2004 & 2 & 0.511 & 64.8 \\
9. Natural vitamin E & 74.6 & 2003 & 6 & 0.827 & 370 \\
10. St John's wort & 28.9 & 2003 & 2 & 0.571 & 33.0 \\
11. St John's wort & 90 & 2003 & 1 & 0.278 & 25.0 \\
12. Valerian & 17.1 & 2003 & 6 & 0.300 & 30.8 \\
13. Valerian & 21.4 & 2003 & 3 & 0.479 & 30.8 \\
14. Valerian & 29.8 & 2004 & 4 & 0.225 & 26.8 \\
\hline
\end{tabular}




\section{Page 35 of 40}

Food Additives and Contaminants

Table 7. Lower bound PAH levels in food supplements ( $N=333$ ) sampled in 2008 and 2009 and percentage of supplements with PAH levels exceeding the LOQ, 1, 2, 5 or $10 \mathrm{\mu g} \mathrm{kg}^{-1}$.

\begin{tabular}{|c|c|c|c|c|c|c|c|c|c|c|}
\hline \multirow[t]{2}{*}{ PAH } & \multicolumn{5}{|c|}{ Product (\%) above limit $\left(\mu \mathrm{g} \mathrm{kg}{ }^{-1}\right)$} & \multicolumn{5}{|c|}{ Concentration $\left(\mu \mathrm{g} \mathrm{kg}^{-1}\right)$} \\
\hline & $>L O Q$ & $>1$ & $>2$ & $>5$ & $>10$ & Median & Mean & P90 & P95 & $\operatorname{Max}$ \\
\hline benz[a]anthracene & 29 & 29 & 29 & 20 & 11 & 0 & 5.18 & 11.0 & 24.2 & 188 \\
\hline benzo[a]pyrene & 63 & 52 & 39 & 23 & 11 & 1.10 & 5.33 & 10.4 & 17.5 & 150 \\
\hline benzo[b]fluoranthene & 57 & 57 & 45 & 27 & 15 & 1.60 & 7.80 & 16.2 & 28.0 & 314 \\
\hline benzo[j]fluoranthene & - & - & & . & - & - & - & - & - & 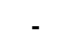 \\
\hline benzo[k]fluoranthene & 65 & 41 & 29 & 13 & 7 & 0.80 & 2.93 & 5.90 & 13.2 & 69.1 \\
\hline benzo[ghi]perylene & 35 & 35 & 34 & 19 & 8 & 0 & 3.37 & 8.02 & 15.1 & 109 \\
\hline chrysene & 50 & 48 & 44 & 36 & 27 & 0 & 15.5 & 32.8 & 91.2 & 368 \\
\hline cyclopenta[cd]pyrene & - & - & - & - & - & - & - & - & - & - \\
\hline dibenz[ah]anthracene & 19 & 14 & 9 & 4 & 2 & 0 & 0.77 & 1.58 & 3.04 & 30.7 \\
\hline dibenzo[a,e]pyrene & 8 & 8 & 5 & 4 & 2 & 0 & 1.01 & 0 & 2.08 & 200 \\
\hline dibenzo[a,h]pyrene & 6 & 4 & 2 & 0 & 0 & 0 & 0.22 & 0 & 0.90 & 36.4 \\
\hline dibenzo[a,]pyrene & 7 & 6 & 4 & 2 & 1 & 0 & 0.29 & 0 & 1.40 & 13.7 \\
\hline dibenzo[a,Ipyrene & 22 & 20 & 16 & 8 & 3 & 0 & 1.70 & 4.10 & 7.32 & 70.1 \\
\hline indeno[1,2,3-cdlpyrene & - & - & - & - & - & - & - & - & - & - \\
\hline 5-methylchrysene & 24 & 22 & 17 & 10 & 7 & 0 & 3.22 & 4.58 & 22.5 & 94.8 \\
\hline benzo[c]fluorene & 21 & 19 & 16 & 8 & 7 & 0 & 5.08 & 3.58 & 12.6 & 503 \\
\hline
\end{tabular}




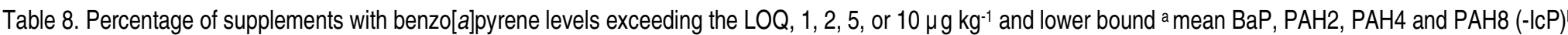
levels in 333 supplements sampled in 2008 and 2009.

\begin{tabular}{|c|c|c|c|c|c|c|c|c|c|c|c|}
\hline \multicolumn{2}{|c|}{ Supplement characteristics } & \multirow[t]{2}{*}{$\mathrm{N}$} & \multicolumn{5}{|c|}{ Product (\%) above limit for $\mathrm{BaP}\left(\mu \mathrm{g} \mathrm{kg}^{-1}\right)$} & \multicolumn{4}{|c|}{ Mean level $\left(\mu \mathrm{g} \mathrm{kg}^{-1}\right)$} \\
\hline Category & Type/ ingredient ${ }^{c}$ & & $>\mathrm{LOQ}$ & $>1$ & $>2$ & $>5$ & $>10$ & $\mathrm{BaP}$ & $\mathrm{PAH} 2$ & $\mathrm{PAH} 4$ & $\mathrm{PAH} 8(-\mathrm{IcP})$ \\
\hline \multirow[t]{3}{*}{ Fatty acids } & $\begin{array}{l}\text { Miscellaneous } \\
\text { Oenothera biennis (evening primrose) }\end{array}$ & 5 & 40 & 40 & 40 & 20 & 0 & 1.94 & 2.78 & 7.50 & 10.5 \\
\hline & seed oil & 7 & 29 & 29 & 29 & 0 & 0 & 0.87 & 7.24 & 9.36 & 9.80 \\
\hline & Fish liver oil & 4 & 25 & 25 & 0 & 0 & 0 & 0.30 & 2.18 & 2.58 & 2.73 \\
\hline \multirow[t]{17}{*}{ Botanical } & Mono-ingredient & 30 & 43 & 33 & 20 & 7 & 0 & 1.06 & 4.62 & 7.23 & 8.79 \\
\hline & Multi-ingredient & 111 & 68 & 53 & 43 & 21 & 9 & 3.69 & 17.5 & 30.0 & 35.6 \\
\hline & Multivitamins with botanicals & 12 & 58 & 58 & 25 & 8 & 8 & 2.93 & 13.7 & 20.3 & 25.3 \\
\hline & Ayurvedic, multi-ingredient & 12 & 67 & 58 & 25 & 17 & 0 & 2.03 & 9.31 & 11.9 & 14.6 \\
\hline & Chinese, multi-ingredient & 11 & 27 & 18 & 18 & 18 & 9 & 4.41 & 17.0 & 38.0 & 42.8 \\
\hline & Actaea racemosa ${ }^{\mathrm{d}}$ (black cohosh) & 7 & 86 & 43 & 14 & 14 & 0 & 1.51 & 2.90 & 7.01 & 9.67 \\
\hline & Angelica sinensis (dong quai) & 4 & 75 & 75 & 50 & 25 & 0 & 3.00 & 9.78 & 15.8 & 20.2 \\
\hline & Camellia sinensis (green tea) & 18 & 89 & 72 & 50 & 28 & 6 & 3.59 & 8.44 & 13.5 & 19.1 \\
\hline & Ginkgo biloba & 22 & 59 & 41 & 27 & 18 & 9 & 4.32 & 31.0 & 46.7 & 53.4 \\
\hline & Glycine max (soy) protein, isoflavones & 9 & 22 & 11 & 0 & 0 & 0 & 0.27 & 1.48 & 2.02 & 2.64 \\
\hline & Hypericum perforatum (St. John's wort) & 14 & 86 & 79 & 71 & 57 & 43 & 6.89 & 22.6 & 40.4 & 55.9 \\
\hline & Panax ginseng (ginseng) & 8 & 50 & 38 & 13 & 0 & 0 & 0.71 & 0.71 & 1.85 & 2.78 \\
\hline & Resveratrole & 7 & 100 & 100 & 86 & 71 & 43 & 36.8 & 111 & 183 & 227 \\
\hline & Resveratrol, multi-ingredient & 14 & 93 & 86 & 86 & 64 & 50 & 36.1 & 101.5 & 152 & 190 \\
\hline & Rhodiola rosea (golden root) & 5 & 80 & 60 & 40 & 20 & 0 & 2.74 & 6.64 & 12.4 & 16.1 \\
\hline & Vaccinum spp. (cranberry) & 5 & 20 & 20 & 20 & 0 & 0 & 0.60 & 0.60 & 1.16 & 1.42 \\
\hline & Valeriana officinalis (valerian) & 8 & 63 & 63 & 63 & 50 & 13 & 4.64 & 8.81 & 20.2 & 24.1 \\
\hline \multirow[t]{2}{*}{ Other } & Miscellaneous, without botanicals & 9 & 33 & 33 & 11 & 11 & 11 & 2.14 & 5.37 & 7.87 & 11.8 \\
\hline & Propolis, pollen, royal jelly & 11 & 91 & 91 & 64 & 45 & 27 & 7.63 & 66.0 & 99.7 & 107 \\
\hline
\end{tabular}

a For a lower bound estimate, values for samples with PAH levels below LOD or LOQ were replaced by 0 .

b (-IcP): indeno[1,2,3-cdlpyrene not analyzed.

c When one ingredient is listed, this substance generally represents the only 'active' ingredient in this group.

d Syn. Cimicifuga racemosa.

e In 6 out of 7 supplements resveratrol was possibly derived from Polygonum cuspidatum-extract. 
Table 9. Examples of daily intake levels of benzo[a]pyrene (BaP), PAH2, PAH4, PAH8 (-IcP) a with supplements when used according to the recommended use level as stated on the label; samples from 2008 and 2009.

\begin{tabular}{|c|c|c|c|c|c|c|}
\hline \multirow[t]{2}{*}{ Food supplement sample } & \multirow{2}{*}{$\begin{array}{l}\text { Maximum dose } \\
\text { (No. of units) }\end{array}$} & \multirow{2}{*}{$\begin{array}{l}\text { Unit weight } \\
\text { (g) }\end{array}$} & \multicolumn{4}{|c|}{ Intake (ng day ${ }^{-1}$ ) } \\
\hline & & & $\mathrm{BaP}$ & $\mathrm{PAH} 2$ & $\mathrm{PAH} 4$ & $\begin{array}{l}\text { PAH8 } \\
(-\mathrm{ICP}) \\
\end{array}$ \\
\hline 1. Chitosan and vitamin $C$ & 2 & 0.657 & 22 & 57 & 82 & 127 \\
\hline 2. Ginkgo biloba & 3 & 0.341 & 14 & 258 & 394 & 436 \\
\hline 3. Ginkgo biloba & 1 & 0.413 & 24 & 112 & 178 & 211 \\
\hline 4. Ginkgo biloba leaf extract and herb, taurine & 1 & 0.492 & 5 & 41 & 64 & 74 \\
\hline 5. Hypericum perforatum extract & 1 & 0.369 & 4 & 21 & 38 & 51 \\
\hline 6. Hypericum perforatum extract & 2 & 0.268 & 8 & 24 & 44 & 57 \\
\hline 7. Multi-ingredient botanical & 4 & 0.521 & 31 & 68 & 130 & 174 \\
\hline 8. Multi-ingredient botanical & 4 & 0.610 & 47 & 130 & 170 & 229 \\
\hline 9. Multi-ingredient botanical & 1 & 0.622 & 15 & 40 & 69 & 91 \\
\hline 10. Multi-ingredient botanical & 1 & 0.409 & 4 & 120 & 152 & 169 \\
\hline $\begin{array}{l}\text { 11. Multi-ingredient botanical with resveratrol from } \\
\text { Polygonum cuspidatum }\end{array}$ & 2 & 0.504 & 39 & 39 & 56 & 93 \\
\hline $\begin{array}{l}\text { 12. Multi-ingredient botanical with resveratrol from } \\
\text { Polygonum cuspidatum }\end{array}$ & 1 & 0.56 & 40 & 156 & 192 & 237 \\
\hline 13. Multi-ingredient botanical with resveratrol & 3 & 0.633 & 171 & 400 & 705 & 934 \\
\hline 14. Multi-ingredient botanical with resveratrol & 2 & 0.28 & 38 & 242 & 283 & 329 \\
\hline 15. Multivitamin with botanicals & 2 & 1.31 & 43 & 282 & 405 & 480 \\
\hline 16. Multivitamin with botanicals & 2 & 0.397 & 18 & 48 & 99 & 130 \\
\hline $\begin{array}{l}\text { 17. Multivitamin with resveratrol from Polygonum } \\
\text { cuspidatum }\end{array}$ & 1 & 0.396 & 23 & 51 & 95 & 131 \\
\hline 18. Polygonum cuspidatum (with resveratrol) & 1 & 0.394 & 59 & 176 & 320 & 398 \\
\hline 19. Polygonum cuspidatum root extract (with resveratrol) & 4 & 1.011 & 76 & 211 & 265 & 378 \\
\hline 20. Polygonum cuspidatum root extract (with resveratrol) & 3 & 0.724 & 146 & 146 & 278 & 346 \\
\hline
\end{tabular}

Note: a(-IcP): indeno[1,2,3-cd]pyrene not analyzed. 
Table 10. Lower bound mean levels of $13 \mathrm{PAH}$ in 333 supplements sampled in 2008 and 2009.

\begin{tabular}{|c|c|c|c|c|c|c|c|c|c|c|c|c|c|c|c|}
\hline \multicolumn{2}{|c|}{ Supplement characteristics } & \multirow[t]{2}{*}{$\mathrm{N}$} & \multicolumn{13}{|c|}{ Mean PAH concentration $\left(\mu \mathrm{g} \mathrm{kg}^{-1}\right)^{\mathrm{b}}$} \\
\hline Category & Type/ ingredient a & & $\mathrm{BaP}$ & $\mathrm{BgP}$ & $\mathrm{BaA}$ & $\mathrm{BbF}$ & BkF & $\mathrm{CHR}$ & $\mathrm{DhA}$ & $\mathrm{DeP}$ & $\mathrm{DhP}$ & $\mathrm{DiP}$ & DIP & $5 \mathrm{MC}$ & $\mathrm{BcL}$ \\
\hline \multirow[t]{3}{*}{ Fatty acids } & $\begin{array}{l}\text { sMiscellaneous } \\
\text { Oenothera biennis (evening primrose) }\end{array}$ & 5 & 1.94 & 1.40 & 0.92 & 3.80 & 1.44 & 0.84 & 0.14 & 0 & 0 & 0 & 0.62 & 0.98 & 0 \\
\hline & seed oil & 7 & 0.87 & 0 & 1.20 & 0.91 & 0.44 & 6.37 & 0 & 0 & 0 & 0.36 & 0.14 & 0.24 & 0 \\
\hline & Fish liver oil & 4 & 0.30 & 0 & 0 & 0.40 & 0.15 & 1.88 & 0 & 0 & 0 & 0 & 0 & 0.68 & 0 \\
\hline \multirow[t]{17}{*}{ Botanical } & Mono-ingredient & 30 & 1.06 & 0.84 & 0.94 & 1.67 & 0.59 & 3.56 & 0.12 & 0 & 0 & 0.05 & 0.45 & 0.57 & 0.34 \\
\hline & Multi-ingredient & 111 & 3.69 & 2.57 & 4.33 & 8.16 & 2.54 & 13.8 & 0.54 & 0.40 & 0.05 & 0.10 & 1.08 & 2.20 & 2.04 \\
\hline & Multivitamin, with botanicals & 12 & 2.93 & 2.86 & 3.14 & 3.53 & 1.74 & 10.7 & 0.36 & 0 & 0 & 0.07 & 0.34 & 0.20 & 1.41 \\
\hline & Ayurvedic, multi-ingredient & 12 & 2.03 & 1.44 & 0.63 & 1.98 & 1.02 & 7.28 & 0.21 & 0.30 & 0 & 0.12 & 0.37 & 10.2 & 2.42 \\
\hline & Chinese, multi-ingredient & 11 & 4.41 & 2.20 & 9.04 & 12.0 & 1.04 & 12.6 & 1.53 & 18.1 & 3.31 & 1.23 & 6.88 & 7.33 & 1.52 \\
\hline & Actaea racemosa ${ }^{c}$ (black cohosh) & 7 & 1.51 & 1.61 & 0.81 & 3.30 & 1.04 & 1.39 & 0 & 0 & 0 & 0 & 0.46 & 0 & 0.41 \\
\hline & Angelica sinensis (dong quai) & 4 & 3.00 & 2.43 & 1.03 & 5.03 & 1.95 & 6.78 & 0 & 0 & 0.23 & 0 & 1.25 & 0.48 & 9.63 \\
\hline & Camellia sinensis (green tea) & 18 & 3.59 & 3.61 & 1.62 & 3.47 & 1.60 & 4.86 & 0.39 & 0.07 & 0.12 & 0.08 & 1.55 & 1.23 & 0.73 \\
\hline & Ginkgo biloba & 22 & 4.32 & 2.40 & 7.18 & 8.5 & 3.82 & 26.7 & 0.53 & 0.35 & 0.13 & 0.37 & 0.20 & 1.65 & 1.23 \\
\hline & $\begin{array}{l}\text { Glycine max (soy) protein, isoflavones } \\
\text { Hypericum perforatum (St. John's }\end{array}$ & 9 & 0.27 & 0 & 0 & 0.54 & 0.28 & 1.21 & 0.34 & 0 & 0 & 0 & 0 & 0 & 0 \\
\hline & wort) & 14 & 6.89 & 6.78 & 7.8 & 9.9 & 5.78 & 15.7 & 2.91 & 0.41 & 0.13 & 0.14 & 2.19 & 2.46 & 3.66 \\
\hline & Panax ginseng (ginseng) & 8 & 0.71 & 0.34 & 0.53 & 0.61 & 0.49 & 0 & 0.10 & 0 & 0 & 0 & 0 & 2.88 & 0.20 \\
\hline & Resveratrol d & 7 & 36.8 & 21.8 & 28.4 & 43.0 & 16.9 & 74.4 & 5.34 & 3.73 & 1.06 & 0.77 & 11,1 & 26.8 & 17.9 \\
\hline & Resveratrol, multi-ingredient & 14 & 36.1 & 19.3 & 15.2 & 35.5 & 14.7 & 65.4 & 3.66 & 1.74 & 0.94 & 3.41 & 11.5 & 6.99 & 76.2 \\
\hline & Rhodiola rosea (golden root) & 5 & 2.74 & 1.90 & 2.94 & 2.80 & 1.38 & 3.90 & 0.44 & 0 & 0.36 & 0 & 0.26 & 0 & 0.54 \\
\hline & Vaccinum spp. (cranberry) & 5 & 0.60 & 0 & 0 & 0.56 & 0.26 & 0 & 0 & 0 & 0 & 0 & 0 & 0 & 0 \\
\hline & Valeriana officinalis (valerian) & 8 & 4.64 & 1.44 & 6.90 & 4.45 & 2.46 & 4.18 & 0 & 0 & 0 & 0 & 1.29 & 0.49 & 0.36 \\
\hline \multirow[t]{2}{*}{ Other } & Miscellaneous, without botanicals & 9 & 2.14 & 3.12 & 0 & 2.50 & 0.83 & 3.22 & 0 & 1.41 & 0 & 0.30 & 1.14 & 2.18 & 0 \\
\hline & Propolis, pollen, royal jelly & 11 & 7.63 & 1.96 & 24.2 & 9.47 & 4.08 & 58.4 & 1.18 & 0.84 & 0 & 0 & 1.16 & 15.4 & 5.37 \\
\hline
\end{tabular}

Notes:

When one ingredient is listed, this substance generally represents the only 'active' ingredient in this group.

b See table 1 for the abbreviations used for the 13 EFSA priority PAH determined in this survey.

d 6 out of 8 supplements labeled a Polygonum cuspidatum-extract as the source of resveratrol. 
Table 11. Lower bound mean BaP, PAH2, PAH4 and PAH8 levels in food supplements calculated from results reported by the FSA in 2005 a.

\begin{tabular}{|c|c|c|c|c|c|c|c|}
\hline \multicolumn{3}{|c|}{ Supplement characteristics } & \multirow[b]{2}{*}{$\mathrm{N}$} & \multicolumn{4}{|c|}{ Mean concentration $\left(\mu \mathrm{g} \mathrm{kg}^{-1}\right)$} \\
\hline $\begin{array}{l}\text { Main } \\
\text { category }\end{array}$ & \multicolumn{2}{|c|}{ Main } & & $\mathrm{BaP}$ & $\mathrm{PAH} 2$ & PAH4 & PAH8d \\
\hline \multirow[t]{4}{*}{ Fatty acids } & Animal Oils & - & 3 & 0.28 & 0.66 & 1.67 & 2.58 \\
\hline & Fish oil & Fish oil & 9 & 0.08 & 0.23 & 0.37 & 0.59 \\
\hline & Combination fish oil & Multi-ingredient & 8 & 0.16 & 1.0 & 1.6 & 1.9 \\
\hline & Plant Oils e & Mono-ingredient & 15 & 0.21 & 1.12 & 1.75 & 2.22 \\
\hline \multirow[t]{6}{*}{ Botanical } & Plant Extracts ${ }^{\dagger}$ & Mono-ingredient & 26 & 6.27 & 26.5 & 48.1 & 61.0 \\
\hline & Garlic & Allium sativum & 10 & 0.47 & 7.03 & 12.1 & 13.6 \\
\hline & Echinacea & Echinacea spp. & 7 & 0.31 & 2.41 & 3.44 & 4.27 \\
\hline & Ginkgo & Ginkgo biloba & 8 & 4.55 & 37.9 & 57.3 & 66.9 \\
\hline & Ginseng & Panax ginseng, Eleutherococcus senticosus & 15 & 3.96 & 11.4 & 21.2 & 29.3 \\
\hline & Other Aquatic Products & Spirulina; miscellaneous, without botanicals & 8 & 6.51 & 55.0 & 91.4 & 112 \\
\hline \multirow[t]{10}{*}{ Other } & Antioxidant & Miscellaneous, without botanicals & 10 & 0.28 & 2.2 & 3.5 & 4.3 \\
\hline & Single Vitamin & Mono-ingredient without botanicals, vitamin $\mathrm{C}$ or $\mathrm{E}$ & 7 & 0.05 & 0.58 & 0.95 & 1.10 \\
\hline & Multivitamin & Miscellaneous, without botanicals & 9 & 0.57 & 1.39 & 2.38 & 3.37 \\
\hline & Multivitamin - Child & Miscellaneous, without botanicals & 10 & 0 & 0.05 & 0.05 & 0.05 \\
\hline & Minerals & Mono-ingredient, without botanicals & 17 & 0 & 0.10 & 0.16 & 0.20 \\
\hline & Calcium & Mono-ingredient, without botanicals & 8 & 0.04 & 0.16 & 0.25 & 0.38 \\
\hline & Iron & Mono-ingredient, without botanicals & 10 & 0.04 & 0.19 & 0.30 & 0.40 \\
\hline & Zinc & Mono-ingredient, without botanicals & 7 & 0.33 & 1.66 & 2.77 & 3.42 \\
\hline & Bee Products & Propolis, pollen, royal jelly & 12 & 4.74 & 42.0 & 61.8 & 73.8 \\
\hline & Glucosamine & Mono-ingredient, without botanicals & 8 & 0.04 & 0.33 & 0.51 & 0.65 \\
\hline
\end{tabular}

Notes:

a Lower bound estimates for the mean BaP, PAH2, PAH4 and PAH8 levels were calculated from results of the FSA survey on PAHs in Dietary supplements from 2005 (FSA 2005 ). The lower bound estimate was calculated by replacing values reported as lower than the LOD or LOQ, by 0 .

b The FSA subcategories were taken from the FSA report (FSA 2005), the FSA category Ginkgo/ Echinacea was separated into one for each botanical however.

cMatching categories found in tables 5, 8 and 10.

$\mathrm{d}$ Including indeno[1,2,3-co]pyrene.

e Including samples with $B$. officinalis, L. usitatissimum and $O$. biennis seed oil, CLA and others.

Including samples with Actaea racemosa, Aloe vera, Angelica sinensis, C. sinensis, G. max, H. perforatum, S. marianum, U. tomentosa, Vaccinum spp., Valeriana officinalis and others 
